\title{
Synthesis of Dinuclear and Trinuclear Ruthenium Cyclopropenyl Complexes
}

\author{
Chiung-Cheng Huang, Ying-Chih Lin,* Shou-Ling Huang, Yi-Hong Liu, and \\ Yu Wang
}

Department of Chemistry, National Taiwan University, Taipe, Taiwan, 106 Republic of China

Received November 4, 2002

\begin{abstract}
Dinuclear ruthenium cyclopropenyl complexes $\{[\mathrm{Ru}] \mathrm{C}=\mathrm{C}(\mathrm{CHR})\}_{2} \mathrm{C}_{6} \mathrm{H}_{4}\left([\mathrm{Ru}]=\left(\eta^{5}\right.\right.$ $\left.\left.\mathrm{C}_{5} \mathrm{H}_{5}\right)(\mathrm{PPh})_{2}\right)_{2} \mathrm{Ru}, \mathrm{R}=\mathrm{CN}$, 3a; $\mathrm{R}=\mathrm{CH}_{2}=\mathrm{CH}_{2}$, 3b; $\left.\mathrm{R}=\mathrm{Ph}, 3 \mathbf{c}\right)$ are prepared by deprotonation of corresponding vinylidene complexes $\left\{[\mathrm{Ru}]=\mathrm{C}=\mathrm{C}\left(\mathrm{CH}_{2} \mathrm{R}\right)\right\}_{2} \mathrm{C}_{6} \mathrm{H}_{4}{ }^{2+}$ (2). For the vinylidene complex $\mathbf{2} \mathbf{d}\left(\mathrm{R}=\mathrm{CO}_{2} \mathrm{Me}\right.$ ) with an ester group, the deprotonation reaction leads to formation of the dinuclear bis-furyl complex $\{[\mathrm{Ru}] \mathrm{C}=\mathrm{C}(\mathrm{CH}=\mathrm{C}(\mathrm{O}) \mathrm{OMe})\}_{2} \mathrm{C}_{6} \mathrm{H}_{4}$ (5d). Electrophilic addition of TCNQ to both three-membered rings of $\mathbf{3 a}$ yields the zwitterionic bis-vinylidene complex $\{[\mathrm{Ru}]=\mathrm{C}=\mathrm{C}[\mathrm{CH}(\mathrm{TCNQ}) \mathrm{CN}]\}_{2} \mathrm{C}_{6} \mathrm{H}_{4}(\mathbf{4 a})$, which, in the presence of $\mathrm{MeOH} / \mathrm{n}-\mathrm{Bu}_{4^{-}}$ $\mathrm{NOH}$, gives the methoxy-substituted bis-cyclopropenyl complex $\{[\mathrm{Ru}] \mathrm{C}=\mathrm{C}(\mathrm{C}(\mathrm{OMe}) \mathrm{CN})\}_{2} \mathrm{C}_{6} \mathrm{H}_{4}$ (6a). The proton-induced demethoxylation of $6 \mathbf{a}$ generates $\{[\mathrm{Ru}] \mathrm{CC}(\mathrm{C}(\mathrm{CN}))\}_{2} \mathrm{C}_{6} \mathrm{H}_{4}{ }^{2+}(\mathbf{7 a})$. The reaction of $\mathrm{TMSN}_{3}$ with $3 a$ gives the bis-tetrazolate complex $\left\{[\mathrm{Ru}]\left(\mathrm{N}_{4} \mathrm{C}\right) \mathrm{CH}\left(\mathrm{CH}_{2^{-}}\right.\right.$

$\mathrm{CN})\}_{2} \mathrm{C}_{6} \mathrm{H}_{4}$ (8a). Trinuclear tris-cyclopropenyl complexes $\left\{[\mathrm{Ru}] \mathrm{C}=\mathrm{C}(\mathrm{CHR}) \mathrm{C}_{6} \mathrm{H}_{4} \mathrm{C} \equiv \mathrm{C}{ }_{3} \mathrm{C}_{6} \mathrm{H}_{3}\right.$ $\left(\mathrm{R}=\mathrm{CN}, \mathbf{1 1 a} ; \mathrm{R}=\mathrm{CH}_{2}=\mathrm{CH}_{2}, \mathbf{1 1} \mathbf{b} ; \mathrm{R}=\mathrm{Ph}, \mathbf{1 1 c}\right)$ are obtained from deprotonation of $\{1,3,5-$ $\left.\left\{[\mathrm{Ru}]=\mathrm{C}=\mathrm{C}\left(\mathrm{CH}_{2} \mathrm{R}\right) \mathrm{C}_{6} \mathrm{H}_{4} \mathrm{C} \equiv \mathrm{C}\right\}_{3} \mathrm{C}_{6} \mathrm{H}_{3}\right\}^{3+}(\mathbf{1 0})$. Complex $\mathbf{2 b}$ is characterized by X-ray diffraction analysis, and other complexes are characterized by spectroscopic methods.
\end{abstract}

\section{Introduction}

Cyclopropene is believed to be the most highly strained cycloalkene, with an estimated strain energy of more than $50 \mathrm{kcal} / \mathrm{mol} .^{1}$ This molecule has hence been under intense investigation ${ }^{2}$ and has played a crucial role in the development of the concept of aromaticity. ${ }^{3}$ Chemical reactivity of this molecule has also been addressed. ${ }^{4-7}$ However, transition metal cyclopropenyl complexes are rare, ${ }^{8}$ even though participation of d orbitals in these complexes is expected to significantly stabilize the

(1) (a) Special issue on strained organic compounds: Chem. Rev. 1989, 89. (b) Liebman, J . F.; Greenberg, A. Strained Organic Mol ecules; Wiley: New York, 1978; p 91.

(2) (a) Marier, G.; Periss, T.; Reisenauer, H. P.; Hess, B. A., J r.; Schand, L. J . J . Am. Chem. Soc. 1994, 116, 2014. (b) Hopf, H.; Plagens, A.; Walsh, R. J . Chem. Soc., Chem. Commun. 1994, 1467.

(3) (a) Liebman, J . F.; Greenberg, A. Chem. Rev. 1976, 76, 311. (b) Halton, B.; Banwell, M. G. In TheChemistry of the Cyclopropnyl Group; Patai, S., Rappoport, Z., Eds.; Wiley: Chichester, 1987; Part 2, Chapter 21, p 1223.

(4) (a) Lahti, P. M.; Berson, J . A. J . Am. Chem. Soc. 1981, 103, 7011. (b) Rigby, J . H.; Kierkus, P. C. J. Am. Chem. Soc. 1989, 111, 4125. (c) Deem, M. L. Synthesis 1972, 675. (d) Galloway, N.; Deut, B. R.; Halton, B. Aust. J . Chem. 1983, 36, 593. (e) Gompper, R.; Choenafinder, K. Chem. Ber. 1979, 112, 1529. (f) Mueller, P.; Bernardinelli, G.; Pfyffer, J .; Schaller, J. P. Helv. Chim. Acta 1991, 74, 993.

(5) Bailey, I. M.; Walsh, R. J . Chem. Soc., Faraday Trans. 1 1978, $74,1146$.

(6) (a) Padwa, A.; Blacklock, T.J J; Getman, D.; Hatanaka, N.; Loza, R. J . Org. Chem. 1978, 43, 1481. (b) Padwa, A. Acc. Chem. Res. 1979, 12, 310. (c) Arnold, D. R.; Humphreys, R. W.; Leigh, W. J .; Palmer, G. E. J . Am. Chem. Soc. 1976, 98, 6625. (d) Zimmerman, H. E.; Aasen, S. M. J . Am. Chem. Soc. 1977, 99, 2342.

(7) (a) Franck-Neumann, M.; Miesch, M.; Kempf, H. Tetrahedron 1988, 44, 2933. (b) Dombrovskii, V. S.; Yakushikina N. I.; Bolesov, I. G. Zh. Org. Khim. 1979, 15, 1184. 24,3 .

(8) Gompper, R.; Bartmann, E. Angew. Chem., Int. Ed. Engl. 1985, mol ecule. Previously we reported the facile synthesis of several mononuclear ruthenium cyclopropenyl complexes ${ }^{9}$ by deprotonation of $\left(\eta^{5}-\mathrm{C}_{5} \mathrm{H}_{5}\right)\left(\mathrm{PPh}_{3}\right)_{2} \mathrm{Ru}=\mathrm{C}=$ $\mathrm{C}(\mathrm{Ph}) \mathrm{CH}_{2} \mathrm{R}^{+}$in which $\mathrm{C}_{\alpha}$ of the vinylidene ligand is known to be electron deficient. Thus deprotonation at $\mathrm{C}_{\gamma}$ causes intramolecular nucleophilic addition at $\mathrm{C}_{\alpha}$, leading to the formation of cyclopropenyl complexes. As applications of dendrimers are currently being investigated for use as biomimetic catalysts, ${ }^{10}$ buil ding blocks for fabrication of designed materials, ${ }^{11}$ molecular carriers for chemical catalysts, ${ }^{12}$ and potential vehicles for delivery of drugs and immunogens, ${ }^{13}$ we extend our synthesis to a few small preliminary dendrimeric systems. Herein we report the preparation of dinuclear and trinuculear ruthenium vinylidene and cyclopropenyl complexes using 1,4-diethynyl benzene and 1,3,5-( $\mathrm{HC} \equiv$ $\left.\mathrm{CC}_{6} \mathrm{H}_{4} \mathrm{C} \equiv \mathrm{C}\right)_{3} \mathrm{C}_{6} \mathrm{H}_{3}{ }^{14}$ as core backbones, respectively.

(9) (a) Ting, P. C.; Lin, Y. C.; Cheng, M. C.; Wang, Y. Organome tallics 1994, 13, 2150. (b) Ting, P. C.; Lin, Y. C.; Lee, G. H.; Cheng, M. C.; Wang, Y.J . Am. Chem. Soc. 1996, 112, 6433. (c) Lo, Y. H.; Lin, Y. C.; Lee, G. H.; Wang, Y. Organometallics 1999, 18, 982. (d) Chang, C. W.; Lin, Y. C.; Lee, G. H.; Wang, Y. Organometallics 2000, 19, 3211.

(10) Huck, W. T. S.; Prins, L.J .; Fokkens, R. H.; Nibbering, N. M. M.; van Veggel, F. C. J . M.; Reinhoudt, D. N.J . Am. Chem. Soc. 1998, 120,6240 .

(11) Mongin, O.; Gossauer, A. Tetrahedron Lett. 1996, 37, 3825.

(12) Knapen, J. W. J .; van der Made, A. W.; de Wilde, J. C.; van Leeuwen, P. W. W. N. M.; Wijkens, P.; Grove, D. M.; van Koten, G. Nature 1994, 372, 659.

(13) (a) Duncan, R.; Kopecek, J . Adv. Polym. Sci. 1984, 57, 51. (b) Peppas, N. A.; Nagai, T.; Miyajima, M. Pharm. Technol. J pn. 1994 10, 611. (c) Bieniarz, C. Dendrimers: Applications to Pharmaceutical and Medicinal Chemistry. In Encycl opedia of Pharmaceutical Technology; Marcel Dekker: New York, 1999; p 55. 
Scheme 1

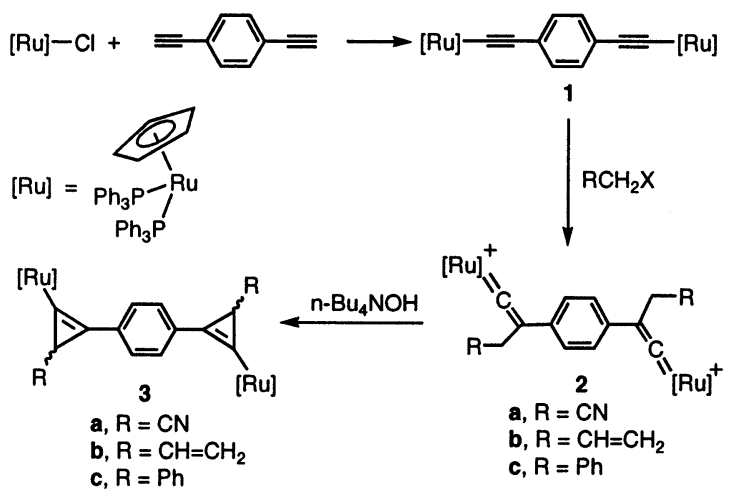

Other dinuclear ruthenium complexes obtained from the bis-vinylidene complex are also reported.

\section{Results and Discussion}

Preparation of Dinuclear Vinylidene Complexes. Treatment of [Ru]Cl with 1,4-diethynylbenzene in the presence of $\mathrm{NaPF}_{6}$ afforded a deep red solution containing a vinylidene intermediate, which underwent deprotonation in the presence of sodium methoxide to give the dinuclear bis-acetylide complex 1 in $84 \%$ yield. ${ }^{15,16}$ With half an equival ent of bisalkyne the reaction yields no mononuclear complex. The singlet resonance at $\delta$ 50.98 in the ${ }^{31}$ P NMR spectrum of $\mathbf{1}$ is in the region of a regular ruthenium acetylide complex. ${ }^{17}$ The mass spectrum of $\mathbf{1}$ gives the parent peaks at $\mathrm{m} / \mathrm{z}=1506$ as well as fragmentations due to loss of phosphines. Bruce and co-workers carried out the reaction of 1,4-bis(trimethylsilylethynyl)benzene with 1 equiv of $[\mathrm{Ru}] \mathrm{Cl}$ in the presence of $\mathrm{KF}$ to give first $[\mathrm{Ru}]\left(\mathrm{C} \equiv \mathrm{CC}_{6} \mathrm{H}_{4} \mathrm{C} \equiv\right.$ $\mathrm{CSiMe}_{3}$ ). Then addition of another equivalent of [Ru] $\mathrm{Cl}$ and $\mathrm{KF}$ cleaved the remaining $\mathrm{C}-\mathrm{Si}$ bond with concomitant formation of the other $\mathrm{Ru}-\mathrm{C}$ bond to afford the same acetylide complex $\mathbf{1}$. Direct use of 2 equiv of $[\mathrm{Ru}] \mathrm{Cl}$ and $\mathrm{KF}$ also afforded $\mathbf{1} .^{18}$

Reactions of $\mathbf{1}$ with various alkyl halides $\mathrm{RCH}_{2} \mathrm{X}$ generate dinuclear bis-vinylidene complexes $\{[\mathrm{Ru}]=\mathrm{C}=$ $\left.\mathrm{C}\left(\mathrm{CH}_{2} \mathrm{R}\right)\right\}_{2} \mathrm{C}_{6} \mathrm{H}_{4}{ }^{2+}$ (2) in high yield (Scheme 1). For example, the reaction of 1 with $\mathrm{ICH}_{2} \mathrm{CN}$ at $40{ }^{\circ} \mathrm{C}$ yields the dicationic bis-vinylidene complex $\left\{[\mathrm{Ru}]=\mathrm{C}=\mathrm{C}\left(\mathrm{CH}_{2-}\right.\right.$ $\mathrm{CN}){ }_{2} \mathrm{C}_{6} \mathrm{H}_{4}{ }^{2+}$ (2a). Several analogous vinylidene complexes $2\left(\mathrm{R}=\mathrm{CH}_{2}=\mathrm{CH}_{2}, \mathbf{2 b} ; \mathrm{R}=\mathrm{Ph}, \mathbf{2 c} ; \mathrm{R}=\mathrm{CO}_{2} \mathrm{CH}_{3}\right.$, $\mathbf{2 d}$; $\mathrm{R}=\mathrm{CO}_{2} \mathrm{Et}, \mathbf{2 e}$ ) are similarly prepared. All these vinylidene complexes, $\mathbf{2} \mathbf{a}-\mathbf{e}$, display a characteristic deep red color and deshielded ${ }^{13} \mathrm{C}$ resonances at $\delta 345$ \pm 5 assignable to $C_{\alpha}$ of the vinylideneligand. ${ }^{19}$ 31P NMR

(14) (a) Uno, M.; Dixneuf, P. H. Angew. Chem., Int. Ed. 1998, 37, 1714. (b) McDonagh, A. M.; Humphrey, M. G.; Samoc, M.; Davies, B. L.; Hiubrechts, S.; Wada, T.; Sasabe, H.; Persoon, A. J . Am. Chem. Soc. 1999, 121, 1405.

(15) Bruce, M. I.; Wallis, R. C. Aust. J . Chem. 1979, 32, 1471.

(16) For general reviews, see: (a) Bruce, M. I.; Swincer, A. G. Adv. Organomet. Chem. 1987, 52, 3940. (b) Bruce, M. I. Chem. Rev. 1991, 91, 197.

(17) (a) Whittall, I. R.; Humphrey, M. G.; Persoons, A.; Houbrechts, S. Organometallics 1996, 15, 1935. (b) Wu, I. Y.; Lin, J . T.; Luo, J .; Li C. S.; Tsai, C.; Wen, Y. S.; Hsu, C. C.; Yeh, F. F.; Liou, S. Organome tallics 1998, 17, 2188.

(18) (a) Bruce, M. I.; Hall, B. C.; Kelly, B. D.; Low, P.J .; Skelton B. W.; White, A. H. J . Chem. Soc., Dalton Trans. 1999, 3719. (b) Bruce, M. I.; Hall, B. C.; Low, P. J .; Skelton B. W.; White, A. H. J . Organomet. Chem. 1999, 592, 74.

(19) Werner, H.; Bachmann, P.; Martin, M. Can. J . Chem. 2001 79,519

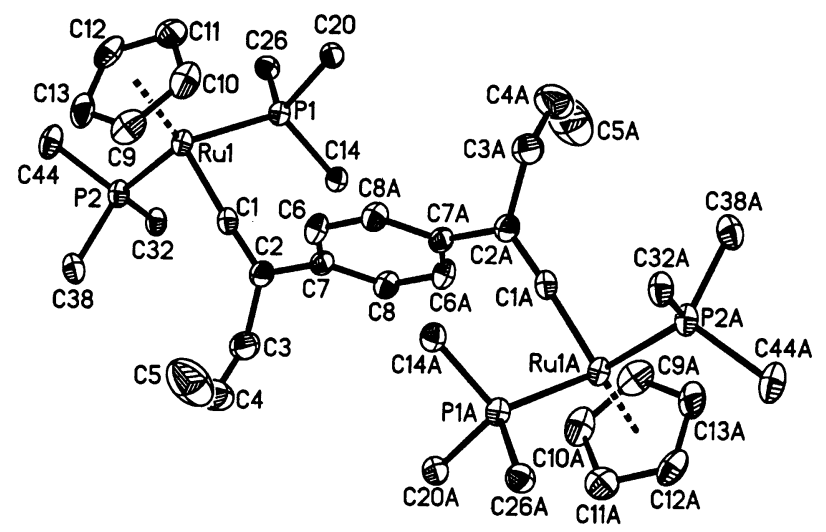

Figure 1. ORTE P drawing of complex $\mathbf{2 b}$ (30\% probability ellipsoids).

Table 1. Selected Bond Distances $(\AA)$ and Angles (deg) of 1,4- $\left\{\text { Ru]C }=\mathbf{C}\left(\mathrm{CH}_{2} \mathbf{C H}=\mathrm{CH}_{2}\right)\right\}_{2} \mathrm{C}_{6} \mathbf{H}_{4}{ }^{2+}(\mathbf{2 b})$

\begin{tabular}{llll}
\hline $\mathrm{Ru}(1)-\mathrm{C}(1)$ & $1.853(4)$ & $\mathrm{Ru}(1)-\mathrm{C}(9)$ & $2.235(4)$ \\
$\mathrm{Ru}(1)-\mathrm{C}(10)$ & $2.240(4)$ & $\mathrm{Ru}(1)-\mathrm{C}(13)$ & $2.243(4)$ \\
$\mathrm{Ru}(1)-\mathrm{C}(11)$ & $2.285(4)$ & $\mathrm{Ru}(1)-\mathrm{C}(12)$ & $2.295(4)$ \\
$\mathrm{Ru}(1)-\mathrm{P}(1)$ & $2.3429(11)$ & $\mathrm{Ru}(1)-\mathrm{P}(2)$ & $2.3708(11)$ \\
$\mathrm{C}(1)-\mathrm{C}(2)$ & $1.311(6)$ & $\mathrm{C}(2)-\mathrm{C}(7)$ & $1.497(6)$ \\
$\mathrm{C}(2)-\mathrm{C}(3)$ & $1.525(7)$ & $\mathrm{C}(3)-\mathrm{C}(4)$ & $1.465(10)$ \\
$\mathrm{C}(4)-\mathrm{C}(5)$ & $1.237(12)$ & & \\
$\mathrm{C}(2)-\mathrm{C}(1)-\mathrm{Ru}(1)$ & $174.0(3)$ & $\mathrm{C}(1)-\mathrm{C}(2)-\mathrm{C}(7)$ & $119.7(4)$ \\
$\mathrm{C}(1)-\mathrm{C}(2)-\mathrm{C}(3)$ & $120.8(4)$ & $\mathrm{C}(7)-\mathrm{C}(2)-\mathrm{C}(3)$ & $119.3(4)$ \\
$\mathrm{C}(4)-\mathrm{C}(3)-\mathrm{C}(2)$ & $116.2(6)$ & $\mathrm{C}(5)-\mathrm{C}(4)-\mathrm{C}(3)$ & $127.5(4)$
\end{tabular}

resonances of 2 appear at around $\delta 42 \pm 1$ in $\mathrm{CDCl}_{3}$ as singlets due to the fluxional behavior of the vinylidene ligand at room temperature. ${ }^{20}$ Complexes $\mathbf{1}$ and $\mathbf{2}$ are less soluble than their corresponding mononuclear complexes. Previously we reported ${ }^{9 b}$ the transformation of a mononuclear ruthenium cyclopropenyl complex to the dimeric dication vinylidene complex $\{[\mathrm{Ru}]=\mathrm{C}=$ $\mathrm{C}(\mathrm{Ph}) \mathrm{CH}(\mathrm{CN})-\}_{2}{ }^{2+}$, which, upon deprotonation, yielded the bis-cycl opropenyl complex $\{[\mathrm{Ru}] \mathrm{C}=\mathrm{C}(\mathrm{Ph}) \mathrm{C}(\mathrm{CN})-\}_{2}$. The two cyclopropenyl groups are bound together directly by the $\mathrm{sp}^{3}$ carbon of the three-membered ring. The formation of this complex probably involves the cationic ruthenium vinylidene radical ${ }^{21}$ formed from the reaction of the mononuclear ruthenium cyclopropenyl complex with allyl iodide.

Single crystals of $\mathbf{2} \mathbf{b}$ suitable for $\mathrm{X}$-ray diffraction analysis are obtained by recrystallization from $\mathrm{CDCl}_{3}$. Complex $\mathbf{2 b}$ crystallized with only one independent molecule in the unit cell and cocrystallized with counterion and chlor oform molecules. The solid-state structure of $\mathbf{2 b}$ is shown in Figure $\mathbf{1}$, and representative bond lengths and bond angles are reported in Table 1 . The molecule possesses an inversion center at the center of the core phenyl group. The $\mathrm{Ru}=\mathrm{C}$ bond length of 1.853(4) $\AA$ is in the range of a regular $\mathrm{Ru}=\mathrm{C}$ bond of other crystallographically characterized ruthenium vinylidene complexes. ${ }^{16 \mathrm{~b}}$ The disorder of an allyl group usually observed for metal complexes containing such a ligand is not observed in $\mathbf{2 b}$, possibly due to bulky phosphine ligands that restrict the number of accessible conforma-

(20) (a) Allen, D. L.; Gibson, V. C.; Green, M. L.; Skinner, T. F.; Bashikin, J .; Grebenik, P. D. J . Chem. Soc., Chem. Commun. 1985 895. (b) Consiglio, G.; Morandini, F. Chem. Rev. 1987, 87, 761.

(21) (a) Rabier, A.; Lugan, N.; Mathieu, R.; Geoffroy, G. L. Organometallics 1994, 13, 4676. (b) Antinolo, A.; Otero, A.; Fajardo, M. Garcia-Yebra, C.; Gil-Sanz, R.; Lopez-Mardomingo, C.; Martin, A.; Gomez-Sal, P. Organometallics 1994, 13, 4679. 
Scheme 2

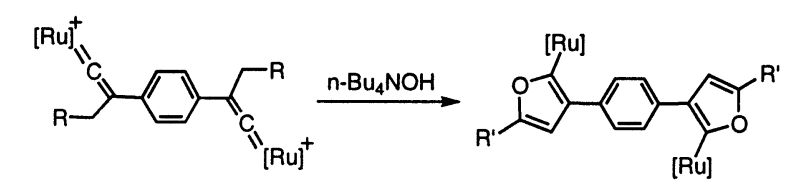

2d, $\mathrm{R}=\mathrm{CO}_{2} \mathrm{Me} ; 2 \mathrm{e}, \mathrm{R}=\mathrm{CO}_{2} \mathrm{Et}$

5d, $R^{\prime}=O M e ; 5 e, R^{\prime}=O E t$

tions. The torsion angle $C(3)-C(2)-C(7)-C(6)$ is 54.9$(5)^{\circ}$ and $\mathrm{C}(1)-\mathrm{C}(2)-\mathrm{C}(7)-\mathrm{C}(8)$ is $60.7(5)^{\circ}$, indicating that the core phenyl group is not coplanar with the vinylidene plane.

Dinuclear Cyclopropenyl and F uryl Complexes. Deprotonation of the vinylidene complex $\mathbf{2 a}$ by $n-\mathrm{Bu}_{4}$ $\mathrm{NOH}$ in acetone is accompanied with a cyclization reaction affording the bis-cycl opropenyl complex $\{[\mathrm{Ru}]-$

$\mathrm{C}=\mathrm{C}(\mathrm{CHCN}){ }_{2} \mathrm{C}_{6} \mathrm{H}_{4}$ (3a). To prevent attack of halide anion to the metal, $\mathrm{NH}_{4} \mathrm{PF}_{6}$ was added. With two stereogenic carbon centers in $\mathbf{3 a}$, it is not surprising to see two sets of coupled doublets at $\delta 51.9,49.3(\mathrm{JP}-\mathrm{P}=$ $36.4 \mathrm{~Hz})$ and 51.8, $49.2(\mathrm{~J} \mathrm{p}-\mathrm{p}=35.2 \mathrm{~Hz})$ in the ${ }^{31} \mathrm{P} N \mathrm{NMR}$ spectrum of $3 a$. The intensity ratio of 1:1 attributed to stereoisomers indicates no diastereoselectivity. For the ${ }^{1} \mathrm{H}$ NMR spectrum of $\mathbf{3 a}$, only in $\mathrm{C}_{6} \mathrm{D}_{6},{ }^{1} \mathrm{H}$ resonances of two diastereomers are distinguishable. Complex $3 \mathbf{a}$ is more stable than the neutral 2,2'-bicyclopropenyl complex $\{[\mathrm{Ru}] \mathrm{C}=\mathrm{C}(\mathrm{Ph}) \mathrm{C} C \mathrm{~N}\}_{2}$ previously reported by us. ${ }^{9 b}$ Using the same method two other dinuclear cyclopropenyl complexes $\left\{[\mathrm{Ru}] \mathrm{C}=\mathrm{C}\left(\mathrm{CHCH}=\mathrm{CH}_{2}\right)\right\}_{2} \mathrm{C}_{6} \mathrm{H}_{4}$ (3b) and $\{[\mathrm{Ru}] \mathrm{C}=\mathrm{C}(\mathrm{CHPh})\}_{2} \mathrm{C}_{6} \mathrm{H}_{4}(3 \mathrm{c})$ are prepared. Characteristic spectroscopic data of $\mathbf{3 b}$ and $\mathbf{3 c}$ are similar to those of $\mathbf{3 a}$. The ${ }^{31} \mathrm{P}$ NMR data of $\mathbf{3 b}$ and $3 c$ reveal the presence of diastereomers both in 1:1 ratio. Protonation of $\mathbf{3}$ readily regenerates $\mathbf{2}$. Preparation of the organic phenyl bridged biscyclopropene 1,4$[\mathrm{PhC}=\mathrm{C}(\mathrm{C}(\mathrm{Ph})(\mathrm{t}-\mathrm{BuO}))] \mathrm{C}_{6} \mathrm{H}_{4}$ by the addition of 1,4-bis(phenylethynyl)benzene to 2 equiv of chlorocarbene PhClC: generated from $\mathrm{Ph}-\mathrm{CHCl}_{2} / \mathrm{t}-\mathrm{BuOK}$ has been reported.22a Additionally, 1,4-bis[3,3-dimethyl-2-(trimethylsilyl)-1-cyclopropen-1-yl]benzene was obtained from the reaction of cyclopropenylzinc chloride and p-diiodobenzene. ${ }^{22 b}$ The unsubstituted 2,2'-bicyclopropene has been prepared, ${ }^{23}$ and its structure has been determined by X-ray diffraction analysis at $103 \mathrm{~K} .{ }^{24}$

However, deprotonation of the dinuclear bis-vinylidene complexes $\mathbf{2} \mathbf{d}$ and $\mathbf{2 e}$, each containing an ester substituent at $\mathrm{C}_{\gamma}$ of the vinylidene ligand, yields the bisfuryl complexes $\left\{[\mathrm{Ru}] \mathrm{C}=\mathrm{C}\left(\mathrm{CH}=\mathrm{C}(\mathrm{O}) \mathrm{OR}^{\prime}\right)\right\}_{2} \mathrm{C}_{6} \mathrm{H}_{4}\left(\mathrm{R}^{\prime}=\right.$ $\left.\mathrm{Me}, \mathbf{5 d} ; \mathrm{R}^{\prime}=\mathrm{Et}, \mathbf{5 e}\right)(\mathrm{Scheme} 2)$. The ${ }^{31} \mathrm{P}$ NMR spectrum of $\mathbf{5 d}$ displays a singlet resonance at $\delta 51.2$, indicating no stereogenic carbon center. ${ }^{9 b}{ }^{31 P}$ NMR data at the initial stage of the reaction indicate formation of a mixture of $\mathbf{5 d}$ and the bis-cyclopropenyl complex $\{[R u]-$ $\mathrm{C}=\mathrm{C}(\mathrm{CHCOOMe})\}_{2} \mathrm{C}_{6} \mathrm{H}_{4}$ (3d); the latter readily converts to $\mathbf{5 d}$ in solution. The less-strained five-membered ring

(22) (a) Eicher T.; Berneth H. Tetrahedron Lett. 1973, 2039. (b) Untiedt S.; de Meijere, A. Chem. Ber. 1994, 127, 1511.

(23) Billups, W. E.; Haley, M. M. Angew. Chem., Int. Ed. Engl. 1989, $28,1711$.

(24) Bordalla, D.; Mootz, D.; Roese, R.; Oswald, W. J . Appl. Crytallogr. 1985, 18, 316.
Scheme 3

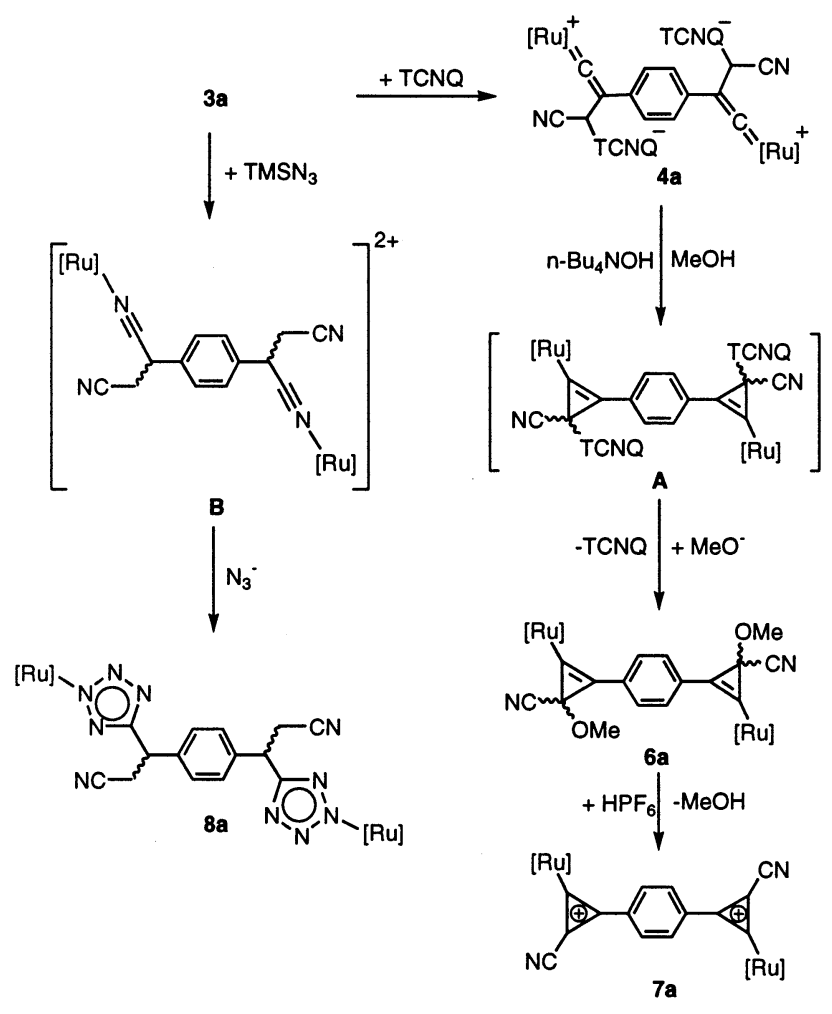

relative to the cyclopropenyl ligand and better oxygen Lewis basicity are driving forces for the formation of $\mathbf{5}$. A few organic bis-furans linked by a phenyl group have been reported.25

Preparation of Dinuclear Cyclopropenylium Complex. Electrophilic addition of TCNQ (tetracyanoquinodimethane) to two $\mathrm{C}_{\gamma}$ of the bis-cyclopropenyl ligand of $\mathbf{3 a}$ leads to the zwitterionic bis-vinylidene complex $\{[\mathrm{Ru}]=\mathrm{C}=\mathrm{C}(\mathrm{CH}(\mathrm{TCNQ}) \mathrm{CN})\}_{2} \mathrm{C}_{6} \mathrm{H}_{4}$ (4a) (Scheme 3). The TCNQ-containing complex $\mathbf{4 a}$ displays a typical deep purple-red color and is only moderately soluble in DMSO. The ${ }^{31} \mathrm{P}$ NMR spectrum displays one set of twodoublet resonances at $\delta 47.2,37.9$ with $\mathrm{J} \mathrm{H}-\mathrm{H}=26.5 \mathrm{~Hz}$. Deprotonation of $\mathbf{4 a}$ in acetone with $\mathrm{n}-\mathrm{Bu}_{4} \mathrm{NOH}$ in $\mathrm{MeOH}$ yields $\left\{[\mathrm{Ru}] \mathrm{C}=\mathrm{C}(\mathrm{C}(\mathrm{OMe}) \mathrm{CN}){ }_{2} \mathrm{C}_{6} \mathrm{H}_{4}(6 \mathbf{a})\right.$, possibly via formation of an unobserved TCNQ-substituted cyclopropenyl complex (A) (Scheme 3). Electrophilic attack of a methoxide at $\mathrm{C}_{\alpha}$ of the three-membered ring accompanied with removal of TCNQ is followed by a migration of the methoxide to $C_{\gamma}$ to give $\mathbf{6 a}$. The chemical reactivity of $\mathbf{6 a}$, containing a methoxy group in the three-membered ring, differs from that of cyclopropenyl complexes with no methoxy group, which, in the presence of acid, readily undergo ringopening to give vinylidene. Protonation of $\mathbf{6 a}$ with $\mathrm{HPF}_{6}$, however, results in demethoxylation, yielding $\{[\mathrm{Ru}] \mathrm{CC}(\mathrm{CCN})\}_{2} \mathrm{C}_{6} \mathrm{H}_{4}{ }^{2+}$ (7a) without opening of the three-membered ring (Scheme 3). This is similar to the reactivity of organic cycl opropene containing a methoxy

(25) (a) Pelter, A.; Rowlands, M.; J enkins, I. H. Tetrahedron Lett 1987, 28, 5213. (b) Teng, X.; Wada, T.; Okamoto, S.; Sato, F. Tetrahedron Lett. 2001, 42, 5501. (c) Kang, S. K.; Baik, T. G.; Song, S. Y. Synth. Lett. 1999, 3, 327. (d) Lee, C. F.; Yang, L.-M.; Hwu, T. Y.; Feng, A. S.; Tseng, J . C.; Luh, T. Y.J . Am. Chem. Soc. 2000, 122, 4992. 
substituent. ${ }^{26}$ The symmetrical planar structure of the three-membered ring in $7 a$ is revealed by its ${ }^{31} \mathrm{P}$ NMR spectrum, which shows only a singlet resonance at $\delta$ 46.8. The reaction of 1,4-bis[3-tert-butoxyl phenyl-2phenyl-1-cyclopropen-1-yl ]benzene with $\mathrm{HClO}_{4}$ resulted in elimination of t-BuOH, leading to a 1,4-bis(diphenylcyclopropenylium)benzene dication.22a

Reaction of $\mathrm{Me}_{3} \mathrm{SiN}_{3}$ with $3 a$. Treatment of $3 a$ with more than 10-fold excess of $\mathrm{Me}_{3} \mathrm{SiN}_{3}$ afforded 1,4-\{[Ru]$\left.\left(\mathrm{N}_{4} \mathrm{C}\right) \mathrm{CH}\left(\mathrm{CH}_{2} \mathrm{CN}\right)\right\}_{2} \mathrm{C}_{6} \mathrm{H}_{4}$ (8a) (Scheme 3). The reaction yields diastereoisomers in a 1:1 ratio, as indicated by two sets of two doublet resonances at $\delta 43.3,41.9$ and $43.1,41.6$ in the 31 P NMR spectrum of the product. The reaction may proceed via an el ectrophilic attack of TMS at $\mathrm{C}_{\gamma}$ of the three-membered ring followed by nucleophilic addition of an azide at $\mathrm{C}_{\alpha}$ with subsequent loss of $\mathrm{N}_{2}$ to first yield an unobserved nitrile complex ${ }^{27}$ (B). Then a $[2+3]$ cycloaddition of the coordinated nitrile ligand with a second azide satisfactorily accounts for formation of the product. Organic tetrazole compounds are usually synthesized via a [3+2] cycloaddition reaction of a nitrile group with azide. ${ }^{28} \mathrm{Metal}$-coordinated azide ligands undergo 1,3-dipolar cycl oaddition reactions with carbon-carbon and carbon-heteroatom multiple bonds. The metals involved are mostly $\mathrm{Pd}(\mathrm{II}),{ }^{29} \mathrm{Pt}(\mathrm{II}),{ }^{30}$ or Co(III), ${ }^{31}$ although a whol e range of other transition metals ${ }^{32-35}$ have been used. However, formation of a tetrazolate ring in our ruthenium complex should not proceed via such a pathway since the reaction of organic nitrile with $[\mathrm{Ru}] \mathrm{N}_{3}$ does not yield the ruthenium tetrazolate complex. ${ }^{27}$

Trinuclear Tris-cyclopropenyl Complexes. Tris(alkynylmetal) derivatives with identical $\mathrm{Pt}(\mathrm{II}),{ }^{36} \mathrm{Fe}$ (II), ${ }^{37}$ or $\mathrm{Ru}(\mathrm{II})^{38}$ moieties have been synthesized from the reaction of 1,3,5-triethynylbenzene with appropriate metal precursors. Weuse the tripodal arylalkynyl ligand $1,3,5-\left(\mathrm{HC} \equiv \mathrm{CC}_{6} \mathrm{H}_{4} \mathrm{C} \equiv \mathrm{C}\right)_{3} \mathrm{C}_{6} \mathrm{H}_{3}$, ${ }^{14 a}$ which is an extended version of 1,3,5-triethynylbenzene. The trinuclear acetyl-

(26) Breslow, R.; Chang, H. W. J . Am. Chem. Soc. 1961, 83, 2367. (b) Krebs, A. W. Angew. Chem., Int. Ed. Engl. 1965, 4, 10. (c) Closs, G. L.; Boll, W. A.; Heyn, H.; Dev, V. J . Am. Chem. Soc. 1968, 90, 173.

(27) (a) Chang, K. H.; Lin, Y. C. Chem. Commun. 1998, 1441. (b) Chang, K. H.; Lin, Y. C.; Liu, Y. H.; Wang, Y. J . Chem. Soc., Dalton Trans. 2001, 3154.

(28) (a) Abbè, G. L. Chem. Rev. 1969, 69, 345. (b) Butler, R. N. Comprehensive Heterocyclic Chemistry; Katritzky, A. R., Rees, C. W., Eds.; Pergamon: Oxford, 1984; Vol. 5, Part 4A, p 791.

(29) (a) Fehlhammer, W. P.; Beck, W. Z. Naturforsch. Teil B 1983 38, 546. (b) Geisenberger, J .; Erbe, J .; Heidrich, J .; Nagel, U.; Beck, W. Z. Naturforsch. Teil B 1987, 42, 55.

(30) Beck, W.: Schorpp, K. Chem. Ber. 1975, 108, 3317.

(31) (a) Hsieh, B. T.; Nelson, J . H.; Milosavljevic, E. B.; Beck, W.; Kemmerich, T. Inorg. Chim. Acta 1987, 133, 267. (b) Kemmerich, T.; Nelson, J . H.; Takach, N. E.; Bohme, H. J ablonski B.; Beck, W. Inorg. Chem. 1982, 21, 1226

(32) Blunden, S. J .; Mahon, M. F.; Molloy, K. C.; Waterfield, P. C. J. Chem. Soc., Dalton Trans. 1994, 2135.

(33) Guilard, R.; Perrot, I.; Tabard, A.; Richard, P.; Lecomte, C. Inorg. Chem. 1991, 30, 19. (b). Guilard, R.; Perrot, I.; Tabard, A.; Richard, P.; Lecomte, C. Inorg. Chem. 1991, 30, 27.

(34) Erbe, J .; Beck, W. Chem. Ber. 1983, 116, 3867.

(35) Nomiya, K.; Noguchi R.; Oda, M. Inorg. Chim. Acta 2000, 298, 24.

(36) Ohshiro, N.; Takei, F.; Onitsuka, K.; Takahashi, S. Chem. Lett. 1996, 871. (b) Khan, M. S.; Schwartz, D. J .; Pasha, N. A.; Kakkar, A K.; Lin, B.; Raithby, R.; Lewis, J. Z. Anorg. Allg. Chem. 1992, 616, 121.

(37) Weyland, T.; Lapinte, C.; Frapper, G.; Calhorda, M. J .; Halet, .-F.; Toupet, L. Organometallics 1997, 16, 2024. (b) Fink, H.; Long N.; J .; Martin, A. J .; Opromolla, G.; White, A. J . P.; Williams, D. J .; Zanello, P. Organometallics 1997, 16, 2646.

(38) Long, N. J .; Martin, A. J .; Biani, F. F. de; Zanello, P. J . Chem. Soc., Dalton Trans. 1998, 2017.

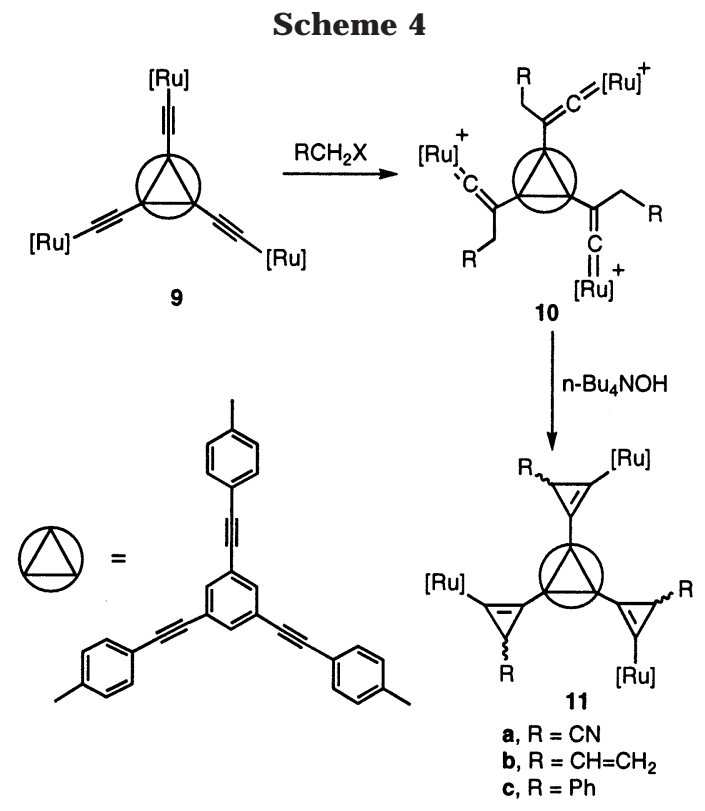

ide complex 1,3,5-\{[Ru]C $\equiv \mathrm{CC}_{6} \mathrm{H}_{4} \mathrm{C} \equiv \mathrm{C}_{3} \mathrm{C}_{6} \mathrm{H}_{3}(\mathbf{9})$ is prepared in $86 \%$ yiel d from the reaction of [Ru]Cl in excess with $1,3,5-\left(\mathrm{HC} \equiv \mathrm{CC}_{6} \mathrm{H}_{4} \mathrm{C} \equiv \mathrm{C}\right)_{3} \mathrm{C}_{6} \mathrm{H}_{3}$. In the ${ }^{1} \mathrm{H} \mathrm{NMR}$ spectrum of $\mathbf{9}$ no signal for alkynyl proton is detected; i.e., a complex with only one or two metals is not observed. The ${ }^{31}$ P NMR spectrum of 9 displays a singlet resonance for six equivalent phosphines at $\delta 50.88$, showing high symmetry of this complex. A similar complex containing different auxiliary ligands on the ruthenium metal center has been reported. ${ }^{14}$ Electrophilic additions of alkyl halide $\mathrm{RCH}_{2} \mathrm{X}$ to three $\mathrm{C}_{\beta}$ atoms of bridging acetylide ligands give the tricationic trisvinylidene complexes $1,3,5-\left\{[\mathrm{Ru}]=\mathrm{C}=\mathrm{C}\left(\mathrm{CH}_{2} \mathrm{R}\right)-\mathrm{C}_{6} \mathrm{H}_{4} \mathrm{C} \equiv\right.$ $\mathrm{C}_{3} \mathrm{C}_{6} \mathrm{H}_{3}{ }^{3+}\left(\mathrm{R}=\mathrm{CN}, 10 \mathrm{a} ; \mathrm{R}=\mathrm{CH}=\mathrm{CH}_{2}, 10 \mathrm{~b} ; \mathrm{R}=\mathrm{Ph}\right.$, 10c) (Scheme 4). Excess organic halide was used to give the single tris-vinylidene product. The downfield ${ }^{13} \mathrm{C}$ NMR resonances at $\delta 345 \pm 5$ and ${ }^{31} \mathrm{P}$ NMR resonances at $\delta 40 \pm 2$ of these complexes clearly indicate the presence of the tris-vinylidene ligand. The tris-vinylidene complexes $\mathbf{1 0}$ are readily deprotonated by $\mathrm{n}-\mathrm{B} \mathrm{u}_{4} \mathrm{NOH}$, leading to the formation of $1,3,5-\{[R u]-$

$\mathrm{C}=\mathrm{C}(\mathrm{CHR}) \mathrm{C}_{6} \mathrm{H}_{4} \mathrm{C} \equiv \mathrm{C}_{3} \mathrm{C}_{6} \mathrm{H}_{3}(\mathrm{R}=\mathrm{CN}$, 11a; $\mathrm{R}=\mathrm{CH}=$ $\mathrm{CH}_{2}, \mathbf{1 1 b} ; \mathrm{R}=\mathrm{Ph}, \mathbf{1 1 c}$ ) (Scheme 4). Again only a single product is obtained; namely, no mixed vinylidenecyclopropenyl complex is observed. There is only one set of AX patterns at $\delta 51.5$ and $49.5\left(\mathrm{~d}, J_{\mathrm{P}-\mathrm{P}}=35.0 \mathrm{~Hz}\right)$ in the ${ }^{31 P}$ NMR spectrum possibly due to distal cyclopropenyl moieties. Tris-cyclopropenyl complexes $\mathbf{1 1}$ gradually decompose in air or in $\mathrm{CDCl}_{3}$, producing the trisacetylide complex $\mathbf{9}$ and some unidentified compounds. Furthermore, tris-cyclopropenyl complexes are less stable than the corresponding mono- and dinuclear cyclopropenyl complexes. The stability of cycl opropenyl complexes follows the trend for trinuclear $<$ dinuclear $<$ mononuclear system.

Concluding Remarks. We report the preparation of dinuclear ruthenium cycl opropenyl complexes $\mathbf{3 a}-\mathbf{c}$ by deprotonation of vinylidene complexes $\mathbf{2} \mathbf{a}-\mathbf{c}$. Diastereomeric pairs in a 1:1 ratio are obtained. However, the deprotonation reaction of complexes $\mathbf{2 d , e}$ each containing an ester substituent at $\mathrm{C}_{\gamma}$ gives the dinuclear bis-furyl complexes 5d,e. Additionally, the bis-methoxysubstituted cyclopropenyl complex $\mathbf{6 a}$ is synthesized 
from the zwitterionic TCNQ-containing bis-vinylidene complex $\mathbf{4 a}$ prepared from $\mathbf{3 a}$. The proton-induced demethoxylation of $\mathbf{6 a}$ generates $\mathbf{7 a}$. The bis-tetrazolate complex 8 a is obtained from the reaction of $\mathrm{TMSN}_{3}$ with 3a. Trinuclear tris-cyclopropenyl complexes $\mathbf{1 1}$ are obtained from deprotonation of trinuclear tris-vinylidene complexes 10, which are readily prepared from $\mathbf{9}$.

\section{Experimental Section}

General Procedures. All manipulations were performed under nitrogen using vacuum-line, drybox, and standard Schlenk techniques. $\mathrm{CH}_{2} \mathrm{Cl}_{2}$ was distilled from $\mathrm{CaH}_{2}$, and diethyl ether and THF were distilled from $\mathrm{Na}$ /diphenylketyl. All other solvents and reagents were of reagent grade and were used as received. NMR spectra were recorded on Bruker AC300 and DMX-500 FT-NMR spectrometers at room temperature (unless stated otherwise) and are reported in units of $\delta$ with residual protons in the solvents as a standard $\left(\mathrm{CDCl}_{3}, \delta\right.$ 7.24; $\mathrm{C}_{6} \mathrm{D}_{6}, \delta$ 7.16). $\mathrm{FAB}$ mass spectra were recorded on a $\mathrm{EOL}$ SX-102A spectrometer. Complex [Ru]Cl $\left([\mathrm{Ru}]=\left(\eta^{5}-\mathrm{C}_{5} \mathrm{H}_{5}\right)\left(\mathrm{PPh}_{3}\right)_{2^{-}}\right.$ $\mathrm{Ru}$ ) was prepared according to the literature method, ${ }^{39}$ as were 1,4-diethynylbenzene ${ }^{40}$ and $1,3,5-\left(\mathrm{HC} \equiv \mathrm{CC}_{6} \mathrm{H}_{4} \mathrm{C} \equiv \mathrm{C}_{3} \mathrm{C}_{6} \mathrm{H}_{3}{ }^{14 \mathrm{a}}\right.$ Elemental analyses and $\mathrm{X}$-ray diffraction studies were carried out at the Regional Center of Analytical Instrument located at National Taiwan University.

Synthesis of 1,4- $\{[R u] C \equiv C\}_{2} \mathbf{C}_{6} \mathbf{H}_{\mathbf{4}}$ (1). A solution of $[R u]-$ $\mathrm{Cl}(230 \mathrm{mg}, 0.32 \mathrm{mmol})$ and $\mathrm{NaPF}_{6}(260 \mathrm{mg}, 1.58 \mathrm{mmol})$ in methanol $(25 \mathrm{~mL})$ was heated to reflux for $40 \mathrm{~min}$ to give an orange-red suspensi on, to which 1,4-diethynyl benzene ( $20 \mathrm{mg}$, $0.16 \mathrm{mmol}$ ) was added. The mixture was heated to reflux for $40 \mathrm{~min}$ and then cooled to room temperature. Addition of 5 equiv of sodium methoxide $(86 \mathrm{mg})$ resulted in rapid precipitation of a yellow powder. The mixture was filtered, and the yellow solid was washed with cold methanol and dried under vacuum to give $\mathbf{1}$ ( $200 \mathrm{mg}, 0.27 \mathrm{mmol}, 84 \%$ ). Spectroscopic data for 1 are as follows. ${ }^{31} \mathrm{P}$ NMR $\left(\mathrm{CDCl}_{3}\right): \delta$ 50.98. ${ }^{1 \mathrm{H}} \mathrm{NMR}$ $\left(\mathrm{CDCl}_{3}\right): \delta 7.45-6.93\left(\mathrm{~m}, 64 \mathrm{H}, \mathrm{Ph}, \mathrm{C}_{6} \mathrm{H}_{4}\right), 4.29\left(\mathrm{~s}, 10 \mathrm{H}, \mathrm{C}_{5} \mathrm{H}_{5}\right)$. MS (FAB) m/z: $1506\left(\mathrm{M}^{+}\right), 1244\left(\mathrm{M}^{+}-\mathrm{PPh}_{3}\right)$. Anal. Calcd for $\mathrm{C}_{92} \mathrm{H}_{74} \mathrm{P}_{4} \mathrm{Ru}_{2}$ : C, 73.39; $\mathrm{H}, 4.95$. Found: $\mathrm{C}, 73.60 ; \mathrm{H}, 4.86$.

Synthesis of $\left\{\mathbf{1}, \mathbf{4}-\left\{[\mathbf{R u}]=\mathbf{C}=\mathbf{C}\left(\mathrm{CH}_{2} \mathbf{C N}\right)\right\}_{2} \mathbf{C}_{6} \mathbf{H}_{4}\right\} \mathbf{I}_{\mathbf{2}}$ (2a). To a Schlenk flask charged with $\mathbf{1}(150 \mathrm{mg}, 0.10 \mathrm{mmol})$ in $\mathrm{CH}_{2-}$ $\mathrm{Cl}_{2}(15 \mathrm{~mL})$ was added $\mathrm{ICH}_{2} \mathrm{CN}(145 \mu \mathrm{L}, 20 \mathrm{mmol})$. The resulting solution was stirred at $40^{\circ} \mathrm{C}$ for $24 \mathrm{~h}$, then cooled to room temperature, and the solvent was reduced to about 2.5 $\mathrm{mL}$. The mixture was slowly added to $25 \mathrm{~mL}$ of vigorously stirred diethyl ether. The red precipitate thus formed was filtered off and washed with diethyl ether and dried under vacuum to give $\mathbf{2 a}$ (169 $\mathrm{mg}, 0.92 \mathrm{mmol}, 92 \%$ yield). Spectro-

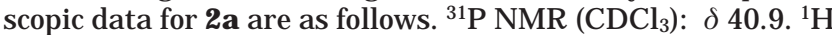
NMR $\left(\mathrm{CDCl}_{3}\right): \delta 7.43-6.89(\mathrm{~m}, 64 \mathrm{H}, \mathrm{Ph}), 5.42\left(\mathrm{~s}, 10 \mathrm{H}, \mathrm{C}_{5} \mathrm{H}_{5}\right)$, $3.42\left(\mathrm{~s}, 4 \mathrm{H}, \mathrm{CH}_{2} \mathrm{CN}\right) .{ }^{13} \mathrm{C} \mathrm{NMR}\left(\mathrm{CD}_{3} \mathrm{SOCD}_{3}\right): \delta 349.2\left(\mathrm{t}, \mathrm{C}_{\alpha}\right.$ J P-C $=15.3 \mathrm{~Hz}), 134.1-129.5(\mathrm{~m}, \mathrm{Ph}), 124.0\left(\mathrm{C}_{\beta}\right), 119.7(\mathrm{CN})$, $96.4(\mathrm{Cp}), 13.4\left(\mathrm{CH}_{2}\right)$. MS (FAB) m/z: $1713\left(\mathrm{M}^{+}-\mathrm{I}\right)$. Anal. Calcd for $\mathrm{C}_{96} \mathrm{H}_{78} \mathrm{~N}_{2} \mathrm{P}_{4} \mathrm{Ru}_{2} \mathrm{I}_{2}: \mathrm{C}, 62.68 ; \mathrm{H}, 4.27 ; \mathrm{N}, 1.52$. F ound: C, $62.44 ; \mathrm{H}, 4.37 ; \mathrm{N}, 1.49$.

Synthesis of $\left\{1,4-\left\{[R u]=C=C\left(C_{2} R\right)\right\}_{2} C_{6} H_{4}\right\} \mathbf{X}_{2}(R=$ $\mathrm{CH}=\mathrm{CH}_{2}$, 2b; $\mathbf{R}=\mathbf{P h}, 2 \mathrm{c} ; \mathbf{R}=\mathrm{CO}_{2} \mathrm{CH}_{3}, 2 \mathrm{~d} ; \mathbf{R}=\mathrm{CO}_{2} \mathrm{C}_{2} \mathrm{H}_{5}$ 2e). Synthesis of $\mathbf{2} \mathbf{b}-\mathbf{e}$ followed the same procedure as that used for the preparation of $\mathbf{2 a}$ from complex $\mathbf{1}(\mathbf{1 5 0} \mathrm{mg}, 0.10$ $\mathrm{mmol}$ ). Spectroscopic data for $\mathbf{2 b}$ (166 mg, $0.90 \mathrm{mmol}, 90 \%$ yield) are as follows. ${ }^{31} \mathrm{P}$ NMR $\left(\mathrm{CDCl}_{3}\right): \delta 42.5 .{ }^{1} \mathrm{H} \mathrm{NMR}$ $\left(\mathrm{CDCl}_{3}\right): \delta 7.44-6.85(\mathrm{~m}, 64 \mathrm{H}, \mathrm{Ph}), 5.31\left(\mathrm{~s}, 10 \mathrm{H}, \mathrm{C}_{5} \mathrm{H}_{5}\right), 5.48$ $5.19(\mathrm{~m}, 2 \mathrm{H},=\mathrm{CH}), 4.78(\mathrm{~d}, 2 \mathrm{H}, \mathrm{J}=5.9 \mathrm{~Hz},=\mathrm{CH}), 4.68(\mathrm{~s}$, $2 \mathrm{H},=\mathrm{CH}), 2.79\left(\mathrm{~d}, 4 \mathrm{H}, \mathrm{CH}_{2}\right) \cdot{ }^{13} \mathrm{C} \mathrm{NMR}\left(\mathrm{CDCl}_{3}\right): \delta 349.2(\mathrm{t}$, $\left.\mathrm{C}_{\alpha}, \mathrm{JP}-\mathrm{C}=15 \mathrm{~Hz}\right), 134.5-127.5\left(\mathrm{~m}, \mathrm{Ph}, \mathrm{CH}_{2}=\mathrm{CH}\right), 117.3\left(\mathrm{C}_{\beta}\right)$,

(39) Bruce, M. I.; Hameister, C. A. Swincer G.; Wallis, R. C. Inorg. Synth. 1990, 28, 270. 2289.
$94.6(\mathrm{Cp}), 30.2\left(\mathrm{CH}_{2}\right)$. MS (FAB) m/z: $1715\left(\mathrm{M}^{+}-1\right)$. Anal. Calcd for $\mathrm{C}_{98} \mathrm{H}_{84} \mathrm{P}_{2} \mathrm{Ru}_{2} \mathrm{I}_{2}: \mathrm{C}, 62.71 ; \mathrm{H}, 4.94$. Found: C, 62.34; $\mathrm{H}, 4.89$. Red single crystals of $\mathbf{2} \mathbf{b}$ are obtained from the $\mathrm{CDCl}_{3}$ solution used for NMR data. Spectroscopic data for 2c (177 $\mathrm{mg}, 0.96 \mathrm{mmol}, 96 \%$ yield) are as follows. ${ }^{31} \mathrm{P} \mathrm{NMR}\left(\mathrm{CDCl}_{3}\right)$ : $\delta$ 42.2. ${ }^{1} \mathrm{H} \mathrm{NMR}\left(\mathrm{CDCl}_{3}\right): \delta 7.33-6.83(\mathrm{~m}, 74 \mathrm{H}, \mathrm{Ph}), 5.34(\mathrm{~s}$, $\left.10 \mathrm{H}, \mathrm{C}_{5} \mathrm{H}_{5}\right), 3.38\left(\mathrm{~s}, 4 \mathrm{H}, \mathrm{CH}_{2}\right) .{ }^{13} \mathrm{C} \mathrm{NMR}\left(\mathrm{CDCl}_{3}\right): \delta 350.3(\mathrm{t}$, $\left.\mathrm{C}_{\alpha}, \mathrm{J} \mathrm{P}-\mathrm{C}=15.3 \mathrm{~Hz}\right), 139.8-127.0(\mathrm{~m}, \mathrm{Ph}), 122.2\left(\mathrm{C}_{\beta}\right), 95.3(\mathrm{Cp})$, $31.8\left(\mathrm{CH}_{2}\right)$. MS (FAB) m/z: $1767\left(\mathrm{M}^{+}-\mathrm{Br}\right)$. Anal. Calcd for $\mathrm{C}_{106} \mathrm{H}_{88} \mathrm{P}_{4} \mathrm{Ru}_{2} \mathrm{Br}_{2}$ : C, 68.90; $\mathrm{H}, 4.80$. Found: C, 69.74; $\mathrm{H}, 4.95$. Spectroscopic data for $2 \mathbf{d}$ (161 mg, $0.89 \mathrm{mmol}, 89 \%$ yiel d) are as follows. ${ }^{31} \mathrm{P} \mathrm{NMR}\left(\mathrm{CDCl}_{3}\right): \delta 41.9 .{ }^{1} \mathrm{H} \mathrm{NMR}\left(\mathrm{CDCl}_{3}\right): \delta 7.48-$ $6.89(\mathrm{~m}, 74 \mathrm{H}, \mathrm{Ph}), 5.42\left(\mathrm{~s}, 10 \mathrm{H}, \mathrm{C}_{5} \mathrm{H}_{5}\right), 3.23\left(\mathrm{~s}, 6 \mathrm{H}, \mathrm{CH}_{3}\right), 2.92$ $\left(\mathrm{s}, 4 \mathrm{H}, \mathrm{CH}_{2}\right) \cdot{ }^{13} \mathrm{C} \mathrm{NMR}\left(\mathrm{CDCl}_{3}\right): \delta 349.6\left(\mathrm{t}, \mathrm{C}_{\alpha}, \mathrm{J} \mathrm{p}-\mathrm{C}=15.0\right.$ $\mathrm{Hz}), 172.3\left(\mathrm{CO}_{2}\right), 135.0-129.3(\mathrm{Ph}), 125.8\left(\mathrm{C}_{\beta}\right), 95.8(\mathrm{Cp}), 52.6$ $\left(\mathrm{CH}_{3}\right), 31.9\left(\mathrm{CH}_{2}\right)$. MS (FAB) m/z: $1731\left(\mathrm{M}^{+}-\mathrm{Br}\right)$. Anal. Calcd for $\mathrm{C}_{98} \mathrm{H}_{84} \mathrm{O}_{4} \mathrm{P}_{4} \mathrm{Ru}_{2} \mathrm{Br}_{2}$ : C, 64.97; $\mathrm{H}$, 4.67. Found: $\mathrm{C}, 65.35 ; \mathrm{H}$, 4.48 Spectroscopic data of 2 e (172 $\mathrm{mg}, 0.91 \mathrm{mmol}, 91 \%$ yield) are as follows. ${ }^{31} \mathrm{P} \mathrm{NMR}\left(\mathrm{CDCl}_{3}\right): \delta 41.9 .{ }^{1} \mathrm{H} \mathrm{NMR}\left(\mathrm{CDCl}_{3}\right): \delta$ 7.51-6.90 (m, 74H, Ph), 5.41 (s, 10H, $\left.\mathrm{C}_{5} \mathrm{H}_{5}\right), 3.77$ (q, 4H, J H-H $\left.=7.1 \mathrm{~Hz}, \mathrm{OCH}_{2}\right), 2.91\left(\mathrm{~s}, 4 \mathrm{H}, \mathrm{CH}_{2} \mathrm{COO}\right), 0.97(\mathrm{t}, 6 \mathrm{H}, \mathrm{J} \mathrm{H}-\mathrm{H}=$ $\left.7.1 \mathrm{~Hz}, \mathrm{CH}_{3}\right) .{ }^{13} \mathrm{C} \mathrm{NMR}\left(\mathrm{CDCl}_{3}\right): \delta 349.3\left(\mathrm{t}, \mathrm{C}_{\alpha}, \mathrm{J} \mathrm{p}-\mathrm{C}=15.0\right.$ $\mathrm{Hz}), 171.8\left(\mathrm{CO}_{2}\right), 135.0-129.4(\mathrm{~m}, \mathrm{Ph}), 126.0\left(\mathrm{C}_{\beta}\right), 95.8(\mathrm{Cp})$, $61.6\left(\mathrm{CH}_{2} \mathrm{CO}_{2}\right), 32.3\left(\mathrm{OCH}_{2}\right), 14.6\left(\mathrm{CH}_{3}\right) . \mathrm{MS}(\mathrm{FAB}) \mathrm{m} / \mathrm{z}: 1767$ $\left(\mathrm{M}^{+}-\mathrm{I}\right)$. Anal. Calcd for $\mathrm{C}_{100} \mathrm{H}_{88} \mathrm{O}_{4} \mathrm{P}_{4} \mathrm{Ru}_{2} \mathrm{I}_{2}$ : $\mathrm{C}, 62.11 ; \mathrm{H}, 4.59$. Found: C, 62.37; $\mathrm{H}, 4.81$.

Synthesis of $1,4-\{[R u] C=C(C H C N)\}_{2} C_{6} \mathbf{H}_{4}$ (3a). To a solution of $2 \mathbf{a}(203 \mathrm{mg}, 0.11 \mathrm{mmol})$ in $10 \mathrm{~mL}$ of $\mathrm{CH}_{2} \mathrm{Cl}_{2}$ was added $\mathrm{NH}_{4} \mathrm{PF}_{6}(41 \mathrm{mg}, 0.25 \mathrm{mmol})$. After stirring at room temperature for $6 \mathrm{~h}$, the mixture was filtered through Celite to remove $\mathrm{NH}_{4} \mathrm{l}$, and the solvent of the filtrate was removed under vacuum. Then $5 \mathrm{~mL}$ of acetone and a solution of $\mathrm{n}-\mathrm{Bu}_{4-}$ $\mathrm{NOH}(2 \mathrm{~mL}, 1 \mathrm{M}$ in $\mathrm{MeOH}$ ) were added. The mixture was stirred for $6 \mathrm{~h}$, yielding yellow microcrystalline precipitates, which were filtered off and washed with $2 \times 5 \mathrm{~mL}$ of acetone, then dried under vacuum. The product contains two diastereomers and is identified as $3 \mathbf{3}$ ( $148 \mathrm{mg}, 0.94 \mathrm{mmol}, 85 \%$ yield). Spectroscopic data for 3a are as follows. ${ }^{31} \mathrm{P} \mathrm{NMR}\left(\mathrm{CDCl}_{3}\right)$ : $\delta$ $51.9(\mathrm{~d}$, J p-p $=36.4 \mathrm{~Hz}), 49.3\left(\mathrm{~d}, J_{\mathrm{p}-\mathrm{p}}=36.4 \mathrm{~Hz}\right), 51.8(\mathrm{~d}$, J p-p $=35.2 \mathrm{~Hz}), 49.2(\mathrm{~d}, \mathrm{~J}-\mathrm{p}=35.2 \mathrm{~Hz})(1: 1) .{ }^{1} \mathrm{H}$ NMR $\left(\mathrm{CDCl}_{3}\right): \delta$ 7.62-6.41 (m, 64H, Ph), $4.28(\mathrm{~s}, 10 \mathrm{H}, \mathrm{Cp}), 1.32(\mathrm{~s}, 2 \mathrm{H}, \mathrm{CH})$. ${ }^{1} \mathrm{H}$ NMR $\left(\mathrm{C}_{6} \mathrm{D}_{6}\right): \delta 7.34-6.86(\mathrm{~m}, 64 \mathrm{H}, \mathrm{Ph}), 4.70,4.69(\mathrm{~s}, 10 \mathrm{H}$, $\mathrm{Cp}), 1.72,1.71(\mathrm{~s}, 2 \mathrm{H}, \mathrm{CH}) .{ }^{13} \mathrm{C}$ NMR $\left(\mathrm{CDCl}_{3}\right): \delta 140.4-128.1$ $\left(\mathrm{m}, \mathrm{Ph}, \mathrm{C}_{\alpha}\right) 120.0(\mathrm{CN}), 86.3(\mathrm{Cp}), 8.8(\mathrm{CH})$. MS (FAB) m/z: $1585\left(\mathrm{M}^{+}+1\right), 1324\left(\mathrm{M}^{+}-\mathrm{PPh}_{3}\right), 1061\left(\mathrm{M}^{+}-2 \mathrm{PPh}_{3}\right)$. Anal. Calcd for $\mathrm{C}_{96} \mathrm{H}_{76} \mathrm{~N}_{2} \mathrm{P}_{4} \mathrm{Ru}_{2}:$ C, $72.81 ; \mathrm{H}, 4.84 ; \mathrm{N}, 1.77$. Found: C, 72.69; H, 4.91; N, 1.81 .

Synthesis of $1,4-\left\{[R u] C=C\left(C H C H=C_{2}\right)\right\}_{2} \mathrm{C}_{6} \mathbf{H}_{4}$ (3b). Complex $\mathbf{3 b}(155 \mathrm{mg}, 0.098 \mathrm{mmol}, 65 \%$ yield) was prepared from $\mathbf{2 b}(276 \mathrm{mg}, 0.15 \mathrm{mmol})$ in analogy with the synthesis of 3a. Spectroscopic data for $\mathbf{3 b}$ are as follows. ${ }^{31 P} \mathrm{NMR}\left(\mathrm{C}_{6} \mathrm{D}_{6}\right)$ : $\delta 53.2(\mathrm{~d}$, J p-p $=37.3 \mathrm{~Hz}), 49.7(\mathrm{~d}$, J p-p $=37.3 \mathrm{~Hz}), 53.1(\mathrm{~d}$, J p-p $=36.9 \mathrm{~Hz}), 49.5(\mathrm{~d}, \mathrm{~J} p-\mathrm{p}=36.9 \mathrm{~Hz}),(1: 1) .{ }^{1} \mathrm{H}$ NMR $\left(\mathrm{C}_{6} \mathrm{D}_{6}\right)$ : $\delta 7.46-6.84(\mathrm{~m}, 74 \mathrm{H}, \mathrm{Ph}), 6.30-6.16(\mathrm{~m}, 2 \mathrm{H},=\mathrm{CH}), 5.63,5.62$ (dd, J $\left.\mathrm{H}_{-\mathrm{H}}=17.0,2.5 \mathrm{~Hz}, 2 \mathrm{H},=\mathrm{CH}\right), 5.13,5.12\left(\mathrm{dd}, \mathrm{J}_{\mathrm{H}-\mathrm{H}}=\right.$ $10.0,2.5 \mathrm{~Hz}, 2 \mathrm{H},=\mathrm{CH}), 4.67(\mathrm{~s}, 10 \mathrm{H}, \mathrm{Cp}), 2.46,2.45(\mathrm{~d}, \mathrm{~J} \mathrm{H}-\mathrm{H}$ $\left.=8.6 \mathrm{~Hz}, 2 \mathrm{H}, \mathrm{CH}_{2}\right) .{ }^{13} \mathrm{C} N M R\left(\mathrm{C}_{6} \mathrm{D}_{6}\right): \delta 154.6(=\mathrm{CH}), 141.2-$ $123.6\left(\mathrm{~m}, \mathrm{Ph}, \mathrm{C}_{\alpha}\right), 106.4\left(=\mathrm{CH}_{2}\right), 86.2(\mathrm{Cp}), 33.5(\mathrm{CH}) . \mathrm{MS}$ $(\mathrm{FAB}) \mathrm{m} / \mathrm{z}: 1587\left(\mathrm{M}^{+}+1\right), 1547\left(\mathrm{M}^{+}+1-\mathrm{CHCH}=\mathrm{CH}_{2}\right), 1326$ $\left(\mathrm{M}^{+}+1-\mathrm{PPh}_{3}\right)$. Anal. Calcd for $\mathrm{C}_{98} \mathrm{H}_{82} \mathrm{P}_{4} \mathrm{Ru}_{2}: \mathrm{C}, 74.23 ; \mathrm{H}$, 5.21. Found: C, 74.01; H, 5.33.

Synthesis of 1,4- $\{\mathbf{R u}] \mathbf{C}=\mathbf{C}(\mathbf{C H P h})\}_{2} \mathbf{C}_{6} \mathbf{H}_{4}$ (3C). Complex 3c (121 mg, $0.072 \mathrm{mmol}, 55 \%$ yield) was prepared from $2 \mathrm{c}$ (240 $\mathrm{mg}, 0.13 \mathrm{mmol}$ ) in anal ogy with the synthesis of 3a. Spectroscopic data for $3 \mathrm{c}$ are as follows. ${ }^{31} \mathrm{P}$ NMR $\left(\mathrm{C}_{6} \mathrm{D}_{6}\right): \delta 54.8$ (d, $J \mathrm{p}-\mathrm{p}=36.8 \mathrm{~Hz}$ ), $48.2(\mathrm{~d}, \mathrm{~J} p-\mathrm{p}=36.8 \mathrm{~Hz}), 54.8(\mathrm{~d}, \mathrm{~J} \mathrm{p}-\mathrm{p}=37.0$ $\mathrm{Hz}), 48.1(\mathrm{~d}, \mathrm{~J}$ p-p $=37.0 \mathrm{~Hz})(1: 1) .{ }^{\mathrm{H}} \mathrm{H}$ NMR $\left(\mathrm{C}_{6} \mathrm{D}_{6}\right): \delta 7.70-$ $6.80(\mathrm{~m}, 74 \mathrm{H}, \mathrm{Ph}), 4.43,4.40(\mathrm{~s}, 10 \mathrm{H}, \mathrm{Cp}), 2.87,2.86(\mathrm{~s}, 2 \mathrm{H}$, $\mathrm{CH}) .{ }^{13} \mathrm{C} \mathrm{NMR}\left(\mathrm{CDCl}_{3}\right): \delta 141.2-123.6\left(\mathrm{~m}, \mathrm{Ph}, \mathrm{C}_{\alpha}\right), 86.1(\mathrm{Cp})$, 
$33.9(\mathrm{CH})$. Anal. Calcd for $\mathrm{C}_{106} \mathrm{H}_{86} \mathrm{P}_{4} \mathrm{Ru}_{2}$ : C, 75.51; $\mathrm{H}, 5.14$. Found: $\mathrm{C}, 75.82 ; \mathrm{H}, 5.06$.

Synthesis of $\left\{[R u] C=C(C H=C(O) O R){ }_{2} \mathrm{C}_{6} \mathrm{H}_{4}(\mathrm{R}=\mathrm{Me}\right.$, $\mathbf{5 d ;} \mathbf{R}=\mathbf{E t}$, 5e). The synthesis and workup were similar to those used in the preparation of complex 3a. Complex 5d (119 $\mathrm{mg}, 0.072 \mathrm{mmol}, 80 \%$ yield) was prepared from $\mathbf{2 d}$ (163 mg, $0.09 \mathrm{mmol}$ ). Spectroscopic data for $\mathbf{5 d}$ are as follows. ${ }^{31} \mathrm{P}$ NMR $\left(\mathrm{CDCl}_{3}\right): \delta 51.2 .{ }^{1} \mathrm{H} \mathrm{NMR}\left(\mathrm{CDCl}_{3}\right): \delta 7.25-6.99(\mathrm{~m}, 64 \mathrm{H}, \mathrm{Ph})$, $5.06(\mathrm{~s}, 2 \mathrm{H}, \mathrm{CH}), 4.10(\mathrm{~s}, 10 \mathrm{H}, \mathrm{Cp}), 3.04\left(\mathrm{~s}, 6 \mathrm{H}, \mathrm{OCH}_{3}\right) .{ }^{13} \mathrm{C}$ NMR $\left(\mathrm{CDCl}_{3}\right): \delta 163.9\left(\mathrm{CO}_{2}\right), 155.0\left(\mathrm{C}_{\alpha}\right), 140.6-127.1(\mathrm{Ph})$, 87.1 $\left(\mathrm{C}_{\gamma}\right), 84.00(\mathrm{Cp}), 58.1\left(\mathrm{CH}_{3}\right)$. Anal. Calcd for $\mathrm{C}_{98} \mathrm{H}_{82} \mathrm{O}_{4} \mathrm{P}_{4-}$ $\mathrm{Ru}_{2}$ : C, 71.35; H, 5.01. Found: C, 71.50; H, 4.89. Complex 5e (110 mg, $0.066 \mathrm{mmol}, 82 \%$ yield) was prepared from $\mathbf{2 e}$ (151 $\mathrm{mg}, 0.08 \mathrm{mmol}$ ). Spectroscopic data for $\mathbf{5 e}$ are as follows. ${ }^{31} \mathrm{P}$ NMR $\left(\mathrm{CDCl}_{3}\right): \delta 51.7 .{ }^{1} \mathrm{H} \mathrm{NMR}\left(\mathrm{CDCl}_{3}\right): \delta 7.35-6.96(\mathrm{~m}, 64 \mathrm{H}$, $\mathrm{Ph}), 5.11(\mathrm{~s}, 2 \mathrm{H}, \mathrm{CH}), 4.11(\mathrm{~s}, 10 \mathrm{H}, \mathrm{Cp}), 3.10(\mathrm{q}, \mathrm{J} \mathrm{H}-\mathrm{H}=7.07$ $\left.\mathrm{Hz}, 4 \mathrm{H}, \mathrm{OCH}_{2}\right), 0.93$ (t, J $\left.\mathrm{H}-\mathrm{H}=7.07 \mathrm{~Hz}, 6 \mathrm{H}, \mathrm{CH}_{3}\right) .{ }^{13} \mathrm{C} N M R$ $\left(\mathrm{CDCl}_{3}\right): \delta 163.2\left(\mathrm{CO}_{2}\right), 155.3\left(\mathrm{C}_{\alpha}\right), 141.6-127.7(\mathrm{Ph}), 89.6\left(\mathrm{C}_{\gamma}\right)$ 84.5 (Cp), $67.3\left(\mathrm{CH}_{2}\right), 15.4\left(\mathrm{CH}_{3}\right)$. Anal. Calcd for $\mathrm{C}_{100} \mathrm{H}_{86} \mathrm{O}_{4} \mathrm{P}_{4^{-}}$ $\mathrm{Ru}_{2}$ : C, 71.59; $\mathrm{H}$, 5.17. Found: $\mathrm{C}, 71.40 ; \mathrm{H}, 5.30$.

Reaction of $3 \mathbf{a}$ with TCNQ. To a mixture of $3 \mathbf{a}$ (40 mg, $0.025 \mathrm{mmol}$ ) in $\mathrm{CH}_{2} \mathrm{Cl}_{2}(5 \mathrm{~mL}$ ) was added TCNQ (10 mg, 0.05 $\mathrm{mmol}$ ). The solution was stirred at room temperature for 40 min, and the solvent was removed under vacuum. The residue was washed with $3 \times 5 \mathrm{~mL}$ of methanol to produce the purplered powder $\mathbf{4 a}$ (46 mg, $0.023 \mathrm{mmol}, 92 \%$ yield). Spectroscopic data for $\mathbf{4 a}$ are as follows. ${ }^{31} \mathrm{P}$ NMR ( $\mathrm{d}_{6}$-DMSO): $\delta 47.2,37.9$ $\left(2 d_{,} J_{p-p}=26.5 \mathrm{~Hz}\right) .{ }^{1} \mathrm{H}$ NMR $\left(\mathrm{d}_{6}-\mathrm{DMSO}\right): \delta 7.62-6.9(\mathrm{~m}, \mathrm{Ph})$, $5.50(\mathrm{~s}, \mathrm{Cp})$.

Synthesis of $1,4-\{[R u] C=C(C(O M e) C N)\}_{2} C_{6} H_{4}(6 a)$. To a solution of $\mathbf{4 a}(120 \mathrm{mg}, 0.06 \mathrm{mmol})$ in $7 \mathrm{~mL}$ of acetone was added $0.7 \mathrm{~mL}$ of $\mathrm{CH}_{3} \mathrm{OH} / \mathrm{n}-\mathrm{Bu}_{4} \mathrm{NOH}$ ( $1 \mathrm{M}$ in $\mathrm{MeOH}$ ). The color of the solution immediately changed to dark green. The solution was further stirred at room temperature for $1.5 \mathrm{~h}$, and then the solvent was removed under vacuum. The residue was washed with $3 \times 5 \mathrm{~mL}$ of methanol to produce yellowgreen microcrystals of complex $6 \mathbf{a}(76 \mathrm{mg}, 0.046 \mathrm{mmol}, 77 \%$ yield). Spectroscopic data for $\mathbf{6 a}$ are as follows. ${ }^{31} \mathrm{P}$ NMR $\left(\mathrm{CDCl}_{3}\right): \delta 51.9(\mathrm{~d}, \mathrm{~J} \mathrm{p}-\mathrm{p}=36.4 \mathrm{~Hz}), 49.9(\mathrm{~d}, \mathrm{~J} \mathrm{p}-\mathrm{p}=36.4 \mathrm{~Hz})$, $51.2(d, J$ p-p $=36.4 \mathrm{~Hz}), 49.3(\mathrm{~d}$, J p-p $=36.4 \mathrm{~Hz})(1: 1) .{ }^{1} \mathrm{H}$ NMR $\left(\mathrm{CDCl}_{3}\right): \delta 7.16-6.39(\mathrm{~m}, 64 \mathrm{H}, \mathrm{Ph}), 4.65(\mathrm{~s}, 10 \mathrm{H}, \mathrm{Cp}), 3.42,3.38$ (s, 6H, OMe). ${ }^{1} \mathrm{H}$ NMR $\left(\mathrm{C}_{6} \mathrm{D}_{6}\right): \delta 7.44-6.68(\mathrm{~m}, 64 \mathrm{H}, \mathrm{Ph}), 4.89$ (s, 10H, Cp), 3.61 (s, 3H, OMe), 3.59 (s, 3H, OMe). MS (FAB) $\mathrm{m} / \mathrm{z}: 1644\left(\mathrm{M}^{+}\right), 1618\left(\mathrm{M}^{+}-\mathrm{CN}\right) .{ }^{13} \mathrm{C} \mathrm{NMR}\left(\mathrm{CDCl}_{3}\right): \delta 139.5-$ $126.7\left(\mathrm{Ph}, \mathrm{C}_{\alpha}\right), 86.3(\mathrm{Cp}), 59.3,59.1$ (C(CN)(OMe)), 55.7, 55.5 (OMe). Anal. Calcd for $\mathrm{C}_{98} \mathrm{H}_{80} \mathrm{O}_{2} \mathrm{~N}_{2} \mathrm{P}_{4} \mathrm{Ru}_{2}: \mathrm{C}, 71.61 ; \mathrm{H}, 4.91$; N, 1.70. Found: C, 71.42; H, 4.99; N, 1.73.

Reaction of 6a with $\mathrm{HPF}_{6}$. To a solution of $\mathbf{6 a}(30 \mathrm{mg}$, $0.018 \mathrm{mmol}$ ) in $2 \mathrm{~mL}$ of $\mathrm{CH}_{2} \mathrm{Cl}_{2}$ at $0{ }^{\circ} \mathrm{C}$ was added $2.5 \mu \mathrm{L}$ of $\mathrm{HPF}_{6}\left(60 \mathrm{wt} \%\right.$ in $\left.\mathrm{H}_{2} \mathrm{O}\right)$. The color of the solution immediately changed from yellow to amber-red. The solution was stirred at $0{ }^{\circ} \mathrm{C}$ for $10 \mathrm{~min}$ and then was added to $10 \mathrm{~mL}$ of an ether solution in an ice-bath. The orange precipitate thus formed was filtered and washed with diethyl ether to give the product $\{[\mathrm{Ru}] \mathrm{CC}(\mathrm{C}(\mathrm{CN}))\}_{2} \mathrm{C}_{6} \mathrm{H}_{4}\left(\mathrm{PF}_{6}\right)_{2}$ (7a). Spectroscopic data for $\mathbf{7 a}$ are as follows. ${ }^{31 P}$ NMR $\left(\mathrm{C}_{6} \mathrm{D}_{6}\right): \delta 46.79 .{ }^{1} \mathrm{H}$ NMR $\left(\mathrm{C}_{6} \mathrm{D}_{6}\right): \delta$ 7.67-6.89 (m, 74H, Ph), $5.20(\mathrm{~s}, 10 \mathrm{H}, \mathrm{Cp})$.

Synthesis of 1,4-\{[Ru] $\left.\mathrm{N}_{4} \mathrm{CCH}\left(\mathrm{CH}_{2} \mathrm{CN}\right)\right\}_{2} \mathrm{C}_{6} \mathrm{H}_{4}$ (8a). To a solution of complex $3 a(30 \mathrm{mg}, 0.019 \mathrm{mmol})$ in THF $(3 \mathrm{~mL})$ was added $\left(\mathrm{CH}_{3}\right)_{3} \mathrm{SiN}_{3}(30 \mu \mathrm{L}, 0.23 \mathrm{mmol})$. After stirring at room temperature for $7 \mathrm{~h}$, the mixture was concentrated to ca. $1 \mathrm{~mL}$ and slowly added to vigorously stirred hexane $(8 \mathrm{~mL})$. The yellow precipitate thus formed was filtered off and washed with $2 \times 5 \mathrm{~mL}$ of hexane. The product was analytically pure and was identified as complex 8a (24 mg, $0.014 \mathrm{mmol}, 75 \%$ yield). Spectroscopic data for $\mathbf{8 a}$ are as follows. ${ }^{31 P}$ NMR $\left(\mathrm{C}_{6} \mathrm{D}_{6}\right): \delta 43.3,41.9(\mathrm{~d}, \mathrm{~J} \mathrm{p}-\mathrm{p}=38.4 \mathrm{~Hz}) 43.1,41.6(\mathrm{~d}, \mathrm{~J} \mathrm{p}-\mathrm{p}=$ $38.2 \mathrm{~Hz})(1: 1)$. ${ }^{1} \mathrm{H}$ NMR $\left(\mathrm{C}_{6} \mathrm{D}_{6}\right): \delta 7.41-6.74(\mathrm{~m}, 64 \mathrm{H}, \mathrm{Ph}), 4.49$, $4.43\left(\mathrm{dd}, 2 \mathrm{H},{ }^{3} \mathrm{~J} \mathrm{H}-\mathrm{H}^{2}=7.75,{ }^{3} \mathrm{H}-\mathrm{H}=7.84 \mathrm{~Hz}\right), 4.29(\mathrm{~s}, 10 \mathrm{H}$, $\mathrm{Cp}), 2.77-2.63,2.47-2.36\left(\mathrm{~m}, 4 \mathrm{H}, \mathrm{CH}_{2}\right) .{ }^{13} \mathrm{C} \mathrm{NMR}\left(\mathrm{CDCl}_{3}\right): \delta$
163.9 (NCN), 138.3-123.6 (Ph), 118.7 (CN), $83.1(\mathrm{Cp}), 39.6$, $39.5(\mathrm{CH}), 23.7,23.5\left(\mathrm{CH}_{2}\right)$. MS (FAB) m/z: $1700\left(\mathrm{M}^{+}\right) 1437$ $\left(\mathrm{M}^{+}-\mathrm{PPh}_{3}\right) 1176\left(\mathrm{M}^{+}-2 \mathrm{PPh}_{3}\right)$. Anal. Calcd for $\mathrm{C}_{96} \mathrm{H}_{78} \mathrm{~N}_{10} \mathrm{P}_{4^{-}}$ $\mathrm{Ru}_{2}$ : $\mathrm{C}, 67.91 ; \mathrm{H}, 4.63 ; \mathrm{N}, 8.25$. Found: $\mathrm{C}, 68.02 ; \mathrm{H}, 4.54 ; \mathrm{N}$, 8.20 .

Synthesis of 1,3,5-\{[Ru]C $\left.\equiv \mathrm{CC}_{6} \mathrm{H}_{4} \mathrm{C} \equiv \mathrm{C}\right\}_{3} \mathrm{C}_{6} \mathrm{H}_{3}$ (9). Complex $[\mathrm{Ru}] \mathrm{Cl}(290 \mathrm{mg}, 0.04 \mathrm{mmol})$ in methanol $(25 \mathrm{~mL})$ was heated to reflux for $40 \mathrm{~min}$ to give an orange-red solution, to which $1,3,5-\left(\mathrm{HC} \equiv \mathrm{CC}_{6} \mathrm{H}_{4} \mathrm{C} \equiv \mathrm{C}\right)_{3} \mathrm{C}_{6} \mathrm{H}_{3}(60 \mathrm{mg}, 0.13 \mathrm{mmol})$ was then added. The mixture was stirred and heated to reflux for $1 \mathrm{~h}$ and then cool ed to room temperature. Addition of 10 equiv of triethylamine resulted in rapid precipitation of a yellow powder. The mixture was stirred for $1 \mathrm{~h}$ and filtered, and the yellow solid washed with cold methanol to give $\mathbf{9}$ (289 $\mathrm{mg}$, $0.034 \mathrm{mmol}, 86 \%$ yield). Spectroscopic data for $\mathbf{9}$ are as follows. 31P NMR $\left(\mathrm{CDCl}_{3}\right): \delta 50.88 .{ }^{1} \mathrm{H}$ NMR $\left(\mathrm{CDCl}_{3}\right): \delta 7.56-7.03(\mathrm{~m}$, $105 \mathrm{H}, \mathrm{Ph}), 4.32(\mathrm{~s}, 15 \mathrm{H}, \mathrm{Cp}) .{ }^{13} \mathrm{C}$ NMR $\left(\mathrm{CDCl}_{3}\right): \delta 138.7(\mathrm{t}$, $\left.\mathrm{C}_{\alpha}, \mathrm{J}_{\mathrm{P}-\mathrm{C}}=20.9 \mathrm{~Hz}\right), 133.8-127.2(\mathrm{Ph}), 85.3(\mathrm{Cp}), 115.3(\equiv \mathrm{C})$, 91.5 , $88.2(\equiv C)$. MS $(F A B) \mathrm{m} / \mathrm{z}: 2521\left(\mathrm{M}^{+}+1\right)$. Anal. Calcd for $\mathrm{C}_{159} \mathrm{H}_{120} \mathrm{P}_{6} \mathrm{Ru}_{3}: \mathrm{C}, 75.79 ; \mathrm{H}, 4.80$. Found: $\mathrm{C}, 75.92 ; \mathrm{H}, 4.64$.

Preparation of $\left\{1,3,5-\left\{[R u]=\mathrm{C}=\mathrm{C}\left(\mathrm{CH}_{2} \mathrm{CN}\right) \mathrm{C}_{6} \mathrm{H}_{4} \mathrm{C} \equiv \mathrm{C}\right\}_{3} \mathrm{C}_{6}\right.$ $\mathbf{H}_{\mathbf{3}} \mathbf{I}_{\mathbf{3}}$ (10a). A Schlenk flask was charged with $\mathbf{9}(330 \mathrm{mg}$, $0.131 \mathrm{mmol})$ in $7 \mathrm{~mL}$ of $\mathrm{CH}_{2} \mathrm{Cl}_{2}$, and $\mathrm{ICH}_{2} \mathrm{CN}(282 \mu \mathrm{L} 3.9$ $\mathrm{mmol}$ ) was added under nitrogen. The resulting solution was stirred at $40{ }^{\circ} \mathrm{C}$ for $24 \mathrm{~h}$, then cooled to room temperature, and the solvent was reduced to about $2.5 \mathrm{~mL}$. The mixture was slowly added to $25 \mathrm{~mL}$ of vigorously stirred diethyl ether. The pale red precipitate thus formed was filtered off and washed with diethyl ether, then dried under vacuum to give 10a (364 mg, $0.120 \mathrm{mmol}, 92 \%$ yield). Spectroscopic data for 10a are as follows. ${ }^{31} \mathrm{P}$ NMR $\left(\mathrm{CDCl}_{3}\right): \delta$ 40.94. ${ }^{1} \mathrm{H}$ NMR $\left(\mathrm{CDCl}_{3}\right): \delta 7.62-6.92(\mathrm{~m}, 105 \mathrm{H}, \mathrm{Ph}), 5.38(\mathrm{~s}, 15 \mathrm{H}, \mathrm{Cp}), 3.55(\mathrm{~s}$, $\left.6 \mathrm{H}, \mathrm{CH}_{2}\right) .{ }^{13} \mathrm{C} \mathrm{NMR}\left(\mathrm{CD}_{3} \mathrm{SOCD}_{3}\right): \delta 345.7\left(\mathrm{t}, \mathrm{C}_{\alpha}, \mathrm{J} \mathrm{p}-\mathrm{C}=15.0\right.$ $\mathrm{Hz}), 134.4-129.5(\mathrm{~m}, \mathrm{Ph}), 124.0\left(\mathrm{C}_{\beta}\right), 119.7(\mathrm{CN}), 96.2(\mathrm{Cp})$, 91.1, $88.8(\equiv \mathrm{C}), 13.4\left(\mathrm{CH}_{2}\right)$. Anal. Calcd for $\mathrm{C}_{165} \mathrm{H}_{126} \mathrm{~N}_{3} \mathrm{P}_{6^{-}}$ $\mathrm{Ru}_{3} \mathrm{l}_{3}$ : $\mathrm{C}, 65.61 ; \mathrm{H}, 4.20 ; \mathrm{N}, 1.39$. Found: $\mathrm{C}, 65.35 ; \mathrm{H}, 4.31 ; \mathrm{N}$, 1.31 .

Preparation of $\left\{1,3,5-\left\{[\mathrm{Ru}]=\mathrm{C}=\mathrm{C}\left(\mathrm{CH}_{2} \mathrm{CH}=\mathrm{CH}_{2}\right) \mathbf{C}_{6} \mathrm{H}_{4} \mathrm{C} \equiv\right.\right.$ C $\left.{ }_{3} \mathbf{C}_{6} \mathbf{H}_{3}\right\}_{3} \mathbf{l}_{3}$ (10b). Complex 10b (376 mg, $0.120 \mathrm{mmol}, 92 \%$ yield) was prepared from $9(330 \mathrm{mg}, 0.131 \mathrm{mmol})$ and $\mathrm{ICH}_{2-}$ $\mathrm{CH}=\mathrm{CH}_{2}$ in analogy with the synthesis of 10a. Spectroscopic data for $\mathbf{1 0 b}$ are as follows. ${ }^{31 \mathrm{P}} \mathrm{NMR}\left(\mathrm{CDCl}_{3}\right): \delta 42.35 .{ }^{1} \mathrm{H}$ NMR $\left(\mathrm{CDCl}_{3}\right): \delta 7.76-6.87(\mathrm{~m}, 105 \mathrm{H}, \mathrm{Ph}), 5.67-5.53(\mathrm{~m}, 3 \mathrm{H}$, $=\mathrm{CH}), 5.17\left(\mathrm{~s}, 15 \mathrm{H}, \mathrm{C}_{5} \mathrm{H}_{5}\right), 5.01\left(\mathrm{~d}, 3 \mathrm{H}, \mathrm{J}=9.9 \mathrm{~Hz},=\mathrm{CH}_{2}\right)$, $4.93\left(\mathrm{~d}, 3 \mathrm{H}, \mathrm{J}=17.1 \mathrm{~Hz},=\mathrm{CH}_{2}\right), 2.79\left(\mathrm{~d}, 4 \mathrm{H}, \mathrm{J}=8.6 \mathrm{~Hz}, \mathrm{CH}_{2}\right)$. ${ }^{13} \mathrm{C}$ NMR $\left(\mathrm{CDCl}_{3}\right): \delta 349.0\left(\mathrm{t}, \mathrm{C}_{\alpha} \mathrm{J} \mathrm{p}-\mathrm{C}=15.5 \mathrm{~Hz}\right), 140.6-122.9$ $(\mathrm{m}, \mathrm{Ph}), 117.9\left(\mathrm{C}_{\beta}\right), 94.8(\mathrm{Cp}), 90.6,88.9(\equiv \mathrm{C}), 30.7\left(\mathrm{CH}_{2}\right)$. Anal. Calcd for $\mathrm{C}_{168} \mathrm{H}_{135} \mathrm{P}_{6} \mathrm{Ru}_{3} \mathrm{I}_{3}$ : $\mathrm{C}, 66.73 ; \mathrm{H}, 4.50$. Found: $\mathrm{C}, 66.91$; H, 4.68.

Preparation of $\left\{1,3,5-\left\{[R u]=C=C\left(\mathrm{CH}_{2} P h\right) \mathbf{C}_{6} \mathrm{H}_{4} \mathrm{C} \equiv \mathrm{C}_{3} \mathrm{C}_{6}-\right.\right.$ $\left.\mathbf{H}_{3}\right\} \mathbf{B r}_{3}$ (10c). Complex $10 \mathrm{c}$ (354 mg, $0.117 \mathrm{mmol}, 89 \%$ yield) was prepared from 9 (330 mg, $0.131 \mathrm{mmol}$ ) and $\mathrm{BrCH}_{2} \mathrm{Ph}$ in anal ogy with the synthesis of $10 \mathrm{a}$. Spectroscopic data for $10 \mathrm{c}$ are as follows. ${ }^{31} \mathrm{P} \mathrm{NMR}\left(\mathrm{CDCl}_{3}\right): \delta 42.10 .{ }^{1} \mathrm{H} \mathrm{NMR}\left(\mathrm{CDCl}_{3}\right): \delta$ 7.57-6.90 (m, 120H, Ph), $5.21(\mathrm{~s}, 15 \mathrm{H}, \mathrm{Cp}), 3.59\left(\mathrm{~s}, 6 \mathrm{H}, \mathrm{CH}_{2}\right)$. ${ }^{13} \mathrm{C}$ NMR $\left(\mathrm{CDCl}_{3}\right): \delta 348.6\left(\mathrm{t}, \mathrm{C}_{\alpha}, \mathrm{J} \mathrm{p}-\mathrm{C}=15.8 \mathrm{~Hz}\right), 137.7-126.7$ $(\mathrm{m}, \mathrm{Ph}), 122.0\left(\mathrm{C}_{\beta}\right), 94.7(\mathrm{Cp}), 90.9,88.6(\equiv \mathrm{C}), 31.8\left(\mathrm{CH}_{2}\right)$. Anal. Calcd for $\mathrm{C}_{180} \mathrm{H}_{141} \mathrm{P}_{6} \mathrm{Ru}_{3} \mathrm{Br} \mathrm{r}_{3}$ : $\mathrm{C}, 71.28 ; \mathrm{H}, 4$.69. Found: $\mathrm{C}, 71.62$; $\mathrm{H}, 4.55$.

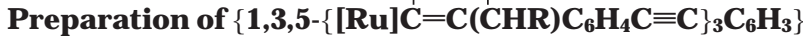
(11a, $\mathbf{R}=\mathbf{C N}$ ). To a solution of $10 \mathrm{a}(302 \mathrm{mg}, 0.10 \mathrm{mmol})$ in $10 \mathrm{~mL}$ of $\mathrm{CH}_{2} \mathrm{Cl}_{2}$ was added $\mathrm{NH}_{4} \mathrm{PF}_{6}(82 \mathrm{mg}, 0.5 \mathrm{mmol}$ ). After stirring at room temperature for $6 \mathrm{~h}$, the mixture was filtered through Celite and the solvent was removed by vacuum. Then $4 \mathrm{~mL}$ of acetone and a solution of $\mathrm{n}-\mathrm{Bu}_{4} \mathrm{NOH}(2 \mathrm{~mL}, 1 \mathrm{M}$ in $\mathrm{MeOH}$ ) were added. After stirring for $8 \mathrm{~h}$, the solvent was reduced to about $1.5 \mathrm{~mL}$. The mixture was slowly added to 8 $\mathrm{mL}$ of vigorously stirred $\mathrm{CH}_{3} \mathrm{CN}$. The yellow precipitate thus formed was filtered off, washed with $\mathrm{CH}_{3} \mathrm{CN}$, and dried under vacuum to gi ve 11 a (217 mg, $0.082 \mathrm{mmol}, 82 \%$ ). Spectroscopic 
data for 11a are as follows. ${ }^{31} \mathrm{P}$ NMR $\left(\mathrm{CDCl}_{3}\right): \delta 51.5,49.5$ (d, $\left.\mathrm{J}_{\mathrm{P}-\mathrm{P}}=35.0 \mathrm{~Hz}\right) .{ }^{1} \mathrm{H} \mathrm{NMR}\left(\mathrm{CDCl}_{3}\right): \delta 7.56-6.54(\mathrm{~m}, 71 \mathrm{H}, \mathrm{Ph})$, $4.58(\mathrm{~s}, 15 \mathrm{H}, \mathrm{Cp}), 1.48(\mathrm{~s}, 3 \mathrm{H}, \mathrm{CH}) .{ }^{13} \mathrm{C} \mathrm{NMR}\left(\mathrm{CDCl}_{3}\right): \delta 138.6-$ $127.4(\mathrm{Ph}), 122.3(\mathrm{CN}), 116.4(\equiv \mathrm{C}), 90.7,85.2(\equiv \mathrm{C}), 86.5(\mathrm{Cp})$, $8.13(\mathrm{CH})$. Anal. Calcd for $\mathrm{C}_{165} \mathrm{H}_{123} \mathrm{~N}_{3} \mathrm{P}_{6} \mathrm{Ru}_{3}$ : C, 75.16; $\mathrm{H}, 4.07$; $\mathrm{N}, 1.59$. Found: $\mathrm{C}, 75.43 ; \mathrm{H}, 4.21 ; \mathrm{N}, 1.44$.

Complex 11b $\left(\mathrm{R}=\mathrm{CH}=\mathrm{CH}_{2}\right)(198 \mathrm{mg}, 0.075 \mathrm{mmol}, 75 \%$ yield) was prepared from $\mathbf{1 0 b}$ (302 $\mathrm{mg}, 0.10 \mathrm{mmol}$ ) in analogy with the synthesis of $\mathbf{1 1 a}$. Spectroscopic data for $\mathbf{1 1 b}$ are as follows. ${ }^{31} \mathrm{P}$ NMR $\left(\mathrm{C}_{6} \mathrm{D}_{6}\right): \delta 53.0,49.5(\mathrm{~d}, \mathrm{~J} \mathrm{p}-\mathrm{p}=36.5 \mathrm{~Hz}) .{ }^{1} \mathrm{H}$ NMR $\left(\mathrm{C}_{6} \mathrm{D}_{6}\right): \delta 7.61-6.84(\mathrm{~m}, 71 \mathrm{H}, \mathrm{Ph}), 6.34-6.22(\mathrm{~m}, 3 \mathrm{H},=$ $\mathrm{CH}$ ), $5.73\left(\mathrm{dd}, \mathrm{J} \mathrm{H}-\mathrm{H}=17.0,2.5 \mathrm{~Hz}, 2 \mathrm{H},=\mathrm{CH}_{2}\right) 5.22(\mathrm{dd}, \mathrm{J} \mathrm{H}-\mathrm{H}$ $\left.=10.0,2.5 \mathrm{~Hz}, 2 \mathrm{H},=\mathrm{CH}_{2}\right) 4.69(\mathrm{~s}, 15 \mathrm{H}, \mathrm{Cp}), 2.57(\mathrm{~d}, \mathrm{~J}-\mathrm{H}=$ $8.6 \mathrm{~Hz}, 3 \mathrm{H}, \mathrm{CH}) .{ }^{13} \mathrm{C} \mathrm{NMR}\left(\mathrm{CDCl}_{3}\right): \delta 153.1(=\mathrm{CH}), 143.1(\mathrm{t}$, $\mathrm{C}_{\alpha}$ J P-C $\left.=20.7 \mathrm{~Hz}\right), 140.2-123.6(\mathrm{Ph}), 117.2\left(\mathrm{C}_{\beta}\right), 106.4$ (= $\left.\mathrm{CH}_{2}\right), 91.8,87.4(\equiv \mathrm{C}), 85.8(\mathrm{Cp}), 32.9(\mathrm{CH})$. Anal. Calcd for $\mathrm{C}_{168} \mathrm{H}_{132} \mathrm{P}_{6} \mathrm{Ru}_{3}$ : C, 76.43; $\mathrm{H}$, 5.04. Found: $\mathrm{C}, 76.98 ; \mathrm{H}, 4.82$.

Complex 11c $(\mathrm{R}=\mathrm{Ph})(173 \mathrm{mg}, 0.062 \mathrm{mmol}, 62 \%$ yield $)$ was prepared from $10 \mathrm{c}(303 \mathrm{mg}, 0.10 \mathrm{mmol}$ ) in analogy with the synthesis of 11a. Spectroscopic data for 11c are as follows. ${ }^{31} \mathrm{P}$ NMR $\left(\mathrm{C}_{6} \mathrm{D}_{6}\right): \delta 54.4,47.6\left(\mathrm{~d}, \mathrm{~J}_{\mathrm{p}-\mathrm{p}}=36.7 \mathrm{~Hz}\right) .{ }^{1} \mathrm{H} \mathrm{NMR}$ $\left(\mathrm{C}_{6} \mathrm{D}_{6}\right): \delta 7.68-6.85(\mathrm{~m}, 86 \mathrm{H}, \mathrm{Ph}), 4.43(\mathrm{~s}, 15 \mathrm{H}, \mathrm{Cp}), 3.0(\mathrm{~s}, 3 \mathrm{H}$, $\mathrm{CH}) .{ }^{13} \mathrm{C} \mathrm{NMR}\left(\mathrm{CDCl}_{3}\right): \delta 143.1\left(\mathrm{t}, \mathrm{C}_{\alpha}, \mathrm{J} \mathrm{P}-\mathrm{C}=20.1 \mathrm{~Hz}\right), 140.6-$ $127.4(\mathrm{Ph}), 117.2\left(\mathrm{C}_{\beta}\right), 91.8,87.5(\equiv \mathrm{C}), 85.3(\mathrm{Cp}), 33.0(\mathrm{CH})$. Anal. Calcd for $\mathrm{C}_{180} \mathrm{H}_{138} \mathrm{P}_{6} \mathrm{Ru}_{3}$ : C, 77.49; $\mathrm{H}, 4.99$. Found: $\mathrm{C}$, 77.26; $\mathrm{H}, 4.84$.

Single-Crystal X-ray Diffraction Analysis of $\mathbf{2 b}$. Single crystals of $\mathbf{2 b}$ suitable for an X-ray diffraction study were grown as mentioned above. A single crystal of dimensions 0.40 $\times 0.20 \times 0.15 \mathrm{~mm}^{3}$ was glued to a glass fiber and mounted on an SMART CCD diffractometer. The diffraction data were collected using $3 \mathrm{~kW}$ sealed-tube molybdenum $\mathrm{K} \alpha$ radiation $(\mathrm{T}=295 \mathrm{~K})$. Exposure time was $5 \mathrm{~s}$ per frame. SADABS (Siemens area detector absorption) absorption correction was applied, and decay was negligible. Data were processed, and the structures were solved and refined by the SHELXTL program. The structure was solved using direct methods and confirmed by Patterson methods refining on intensities of all data (67 315 reflections) to give $R 1=0.0531$ and $w R 2=0.1325$ for 12547 unique observed reflections $(I>2 \sigma(I))$. Hydrogen atoms were placed geometrically using the riding model with thermal parameters set to 1.2 times that for the atoms to
Table 2. Crystal and Intensity Collection Data for $1,4-\left\{[R u] C=C\left(\mathrm{CH}_{2} \mathrm{CH}=\mathrm{CH}_{2}\right)\right\}_{2} \mathrm{C}_{6} \mathrm{H}_{4}{ }^{2+}(2 \mathrm{~b})$

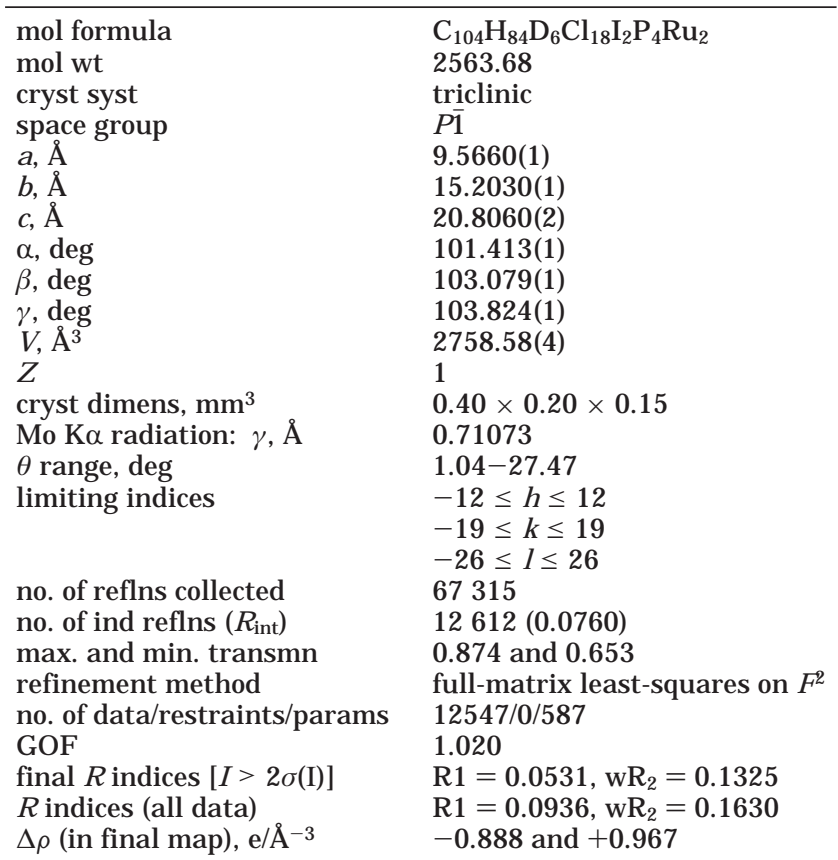

which the hydrogen is attached and 1.5 times that for the methyl hydrogens. (Data collection parameters are listed in Table 2.)

Acknowledgment. We thank the National Science Council, Taiwan, Republic of China, for support of this work.

Supporting Information Available: Tables of atomic coordinates, bond lengths and angles, anisotropic thermal parameters, and hydrogen atom positions for $\mathbf{2} \mathbf{b}$. This material is available free of charge via the Internet at http://pubs.acs.org.

OM020913X 